\title{
The Application of Crystallographic Interpretation on Technical Study of Gypsum-Based Historical Materials (Case studies of stucco decoration of Kuh-e Khwaja and Gypsum Mortars from Shadiakh and Alamut)
}

\author{
M. MISHMASTNEHI * \\ PhD Candidate in Archaeology, Institut für Vorderasiatische, Department of History and Cultural Studies \\ Freie Universität Berlin, GERMANY
}

\begin{abstract}
Investigation of gypsum-based historical materials has two main problems: philological problems and technical issues. Technical issues, the main topic of this article, are normally consequences of physicochemical complexity of gypsum crystals in different conditions and variety of additives or mixed materials. Neglecting this technical problem, leads researchers to misunderstand or misinterpret these materials. Moreover, exclusively use of one analytical method, such as scanning electron microscope or X-ray fluorescence, provides an incomplete picture of samples that regularly produces further misunderstanding of specimen or its history. The methodology of this study is a multianalytical approach via XRD, SEM and using image analysis software on electron photomicrographs to estimate amount of free spaces in microstructure of samples. A group of three experimental samples were made from traditional recipes of craftsmen in Iran, in order to make a connection between philological problems came from tradition, and technical problems came from mineralogical property of gypsum. Gach-e Tiz, or quick setting mortar shows a very dense microstructure in SEM micrographs. Variety sizes of monoclinic crystals of gypsum are present in it, and moreover some shapeless and bulky regions are also visible. Gach-e Kam-Mayeh, or low setting mortar reveals a much more open microstructure than the former one, filled with needle like crystals and a lot of micro porosity between crystals. There is no evidence of bulky forms area in Gach-e Kam-Mayeh. Gach-e Koshteh, or mechanical low-setting mortar which is a traditional Iranian recipe, shows a parallel layers of laminar gypsum crystals setting upon each other. This form also demonstrates no evidence of bulky regions. Historical samples were collected from a stucco decoration belong to Kuh-e Khwaja of Sistan; a gypsum mortar fragment from Shadyakh, Neyshabur and a piece of gypsum mortar from Alamut castle of Qazvin. The results of XRD show that both layers of Kuh-e Khwaja stucco contain anhydrite as the major phase and the sample of Shadiyakh mostly composed of Gypsum. Organic materials extractions represent no evidence of organic additive to this historical materials. Therefore the images of their microstructure are comparable with experimental samples that made without any additive. Lower layer of Kuh-e Khwaja's stucco shows a lot of tiny crystals that are not very look like gypsum, but precipitated on the surface of bigger and deformed crystals. The microstructure of it is very open and include big amount of micro porosity in compare with other samples. Upper layer of this stucco shows not any form of gypsum crystals but very disturbed flaked shapes, supposedly gypsum crystals transformed to anhydrate. The micrographs of Shadiyakh's mortar also reveal not any clear form of gypsum crystals but base on XRD result it still as gypsum materials. This sample contains mostly from that bulky and dense structure which shows the usage of low amount of water for its paste. The results of image analysis on electron micrographs at magnification of $\times 250$ and $\times 500$ provide a good and comparable estimation for free space evaluation in the micro structure of gypsum based materials. The combination of these techniques and methods lead to better understanding of gypsum based historical materials.
\end{abstract}

Keywords: Gypsum-Based Historical Materials, Crystallography, Technical study, pathology, SEM, XRD.

* - Corresponding author: mmishmast@zedat.fu-berlin.de 


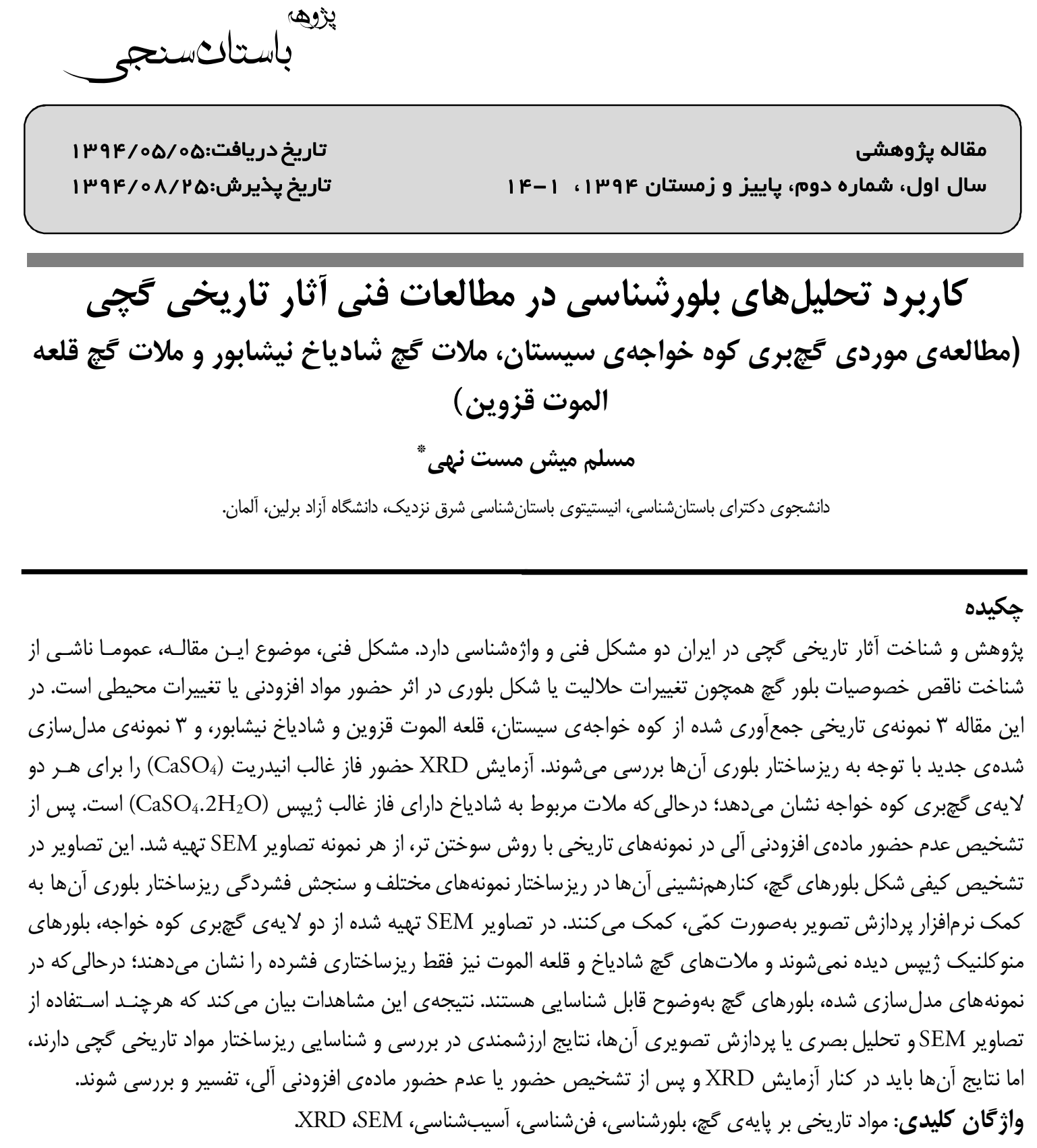

mmishmast@zedat.fu-berlin.de مكاتبات"

C) حق نشر متعلق به نويسنده(كان) است و نويسنده تحت مجوز Creative Commons Attribution License به مجله اجازه مىدهد مقاله حاب شده

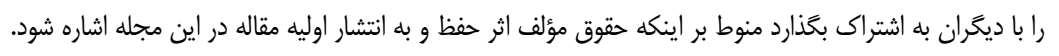


ويزَىهاى فيزيكى و شيميايى بلورهاى گَج و حساسـيت

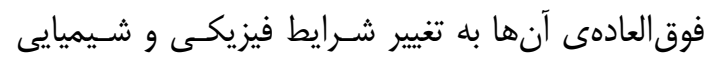
محيط اطرافشان است. به اين معنى كه در اثر حضور مواد

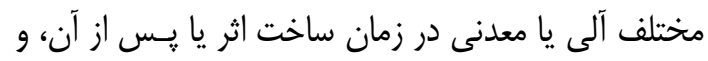

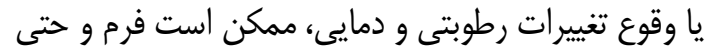

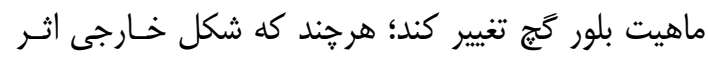

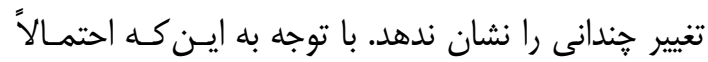

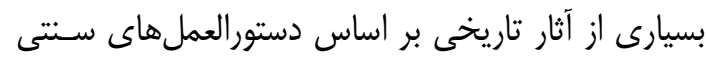

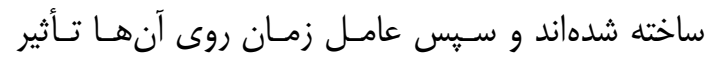

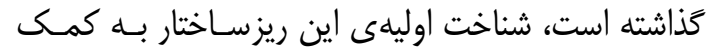

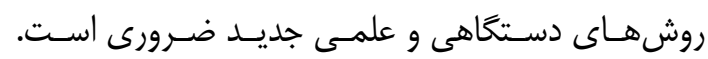

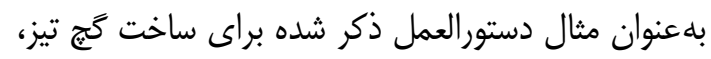
كَ تيزون، كج زنده و گج يرمايه بيانكر نسبت آب اختلاط

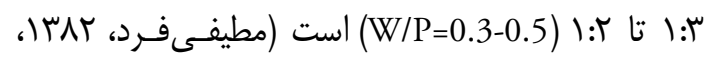

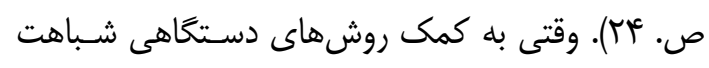

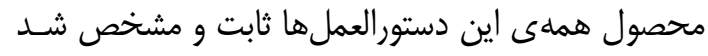

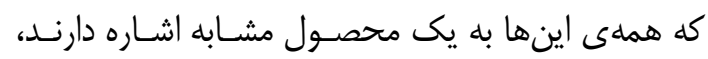

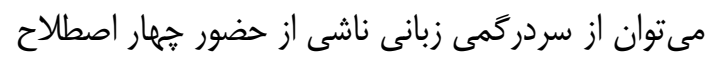

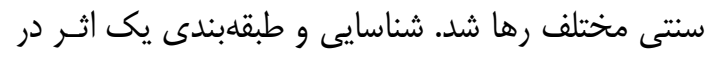
زيرشاخههاى مختلف مصالح سنتى يا آرايههاى معمارى،

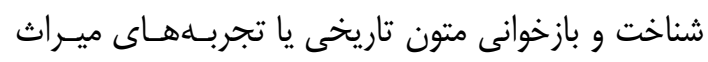

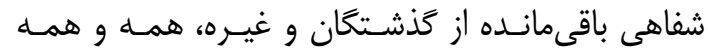

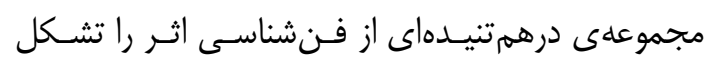

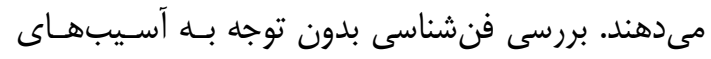

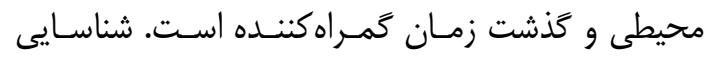

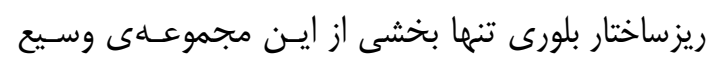

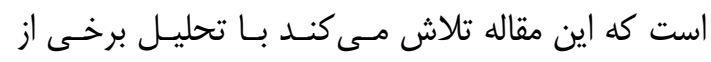

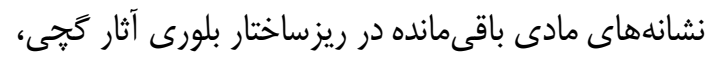

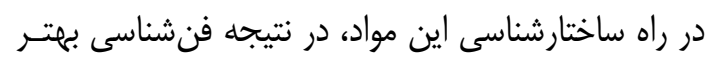

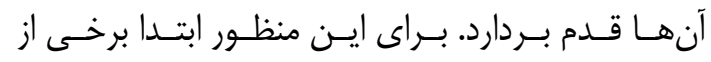

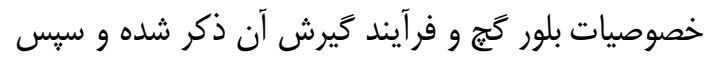

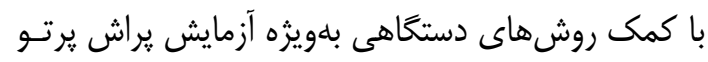

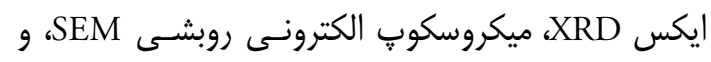

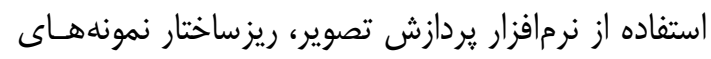

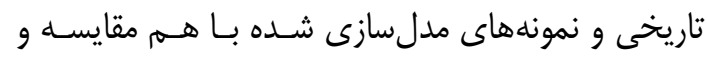

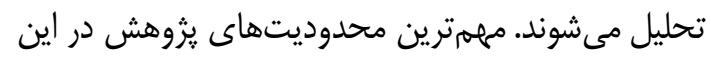

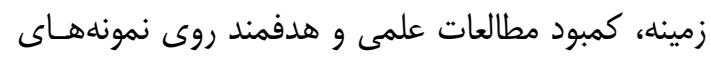

| - (- مقدمه

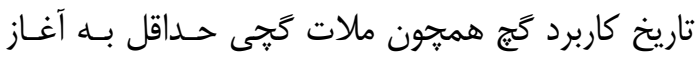

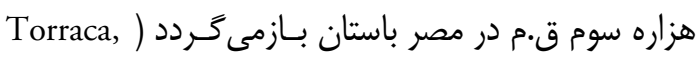
1982, p. 65

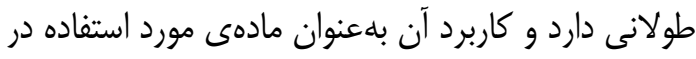

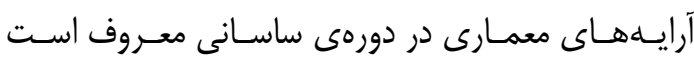

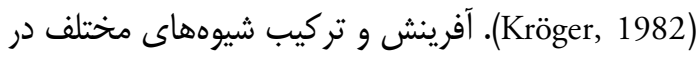
ساخت تزئينات گَّى در دورهى اسلامى سبب شده است

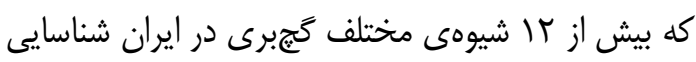

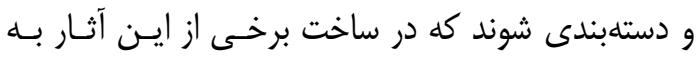

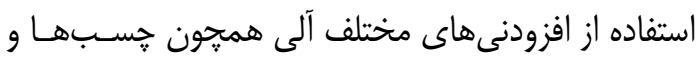
بستها يا افزودنى هاى معدنى همجيون رنغخدانهها اشـاره

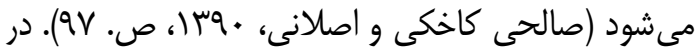

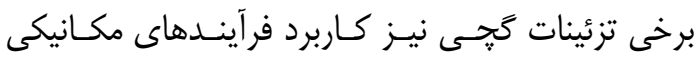

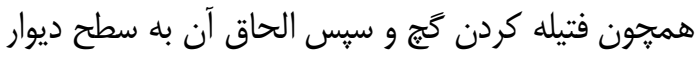

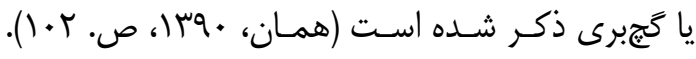

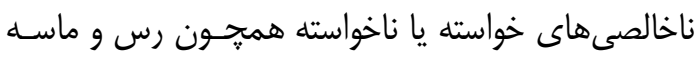
نيز تقريباً هميشه به مقدار كم يا زياد حضور دارند.

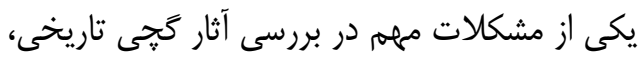

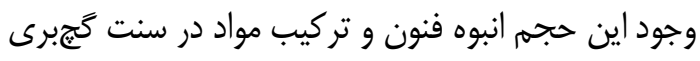

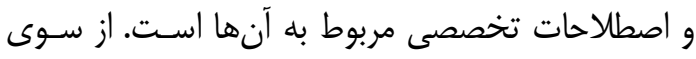
ديخر ترجمهى متون علمى جديد مرتبط با زمين شناسى يا لاصنا

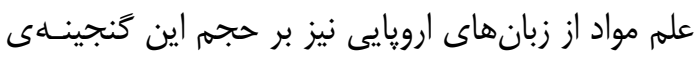

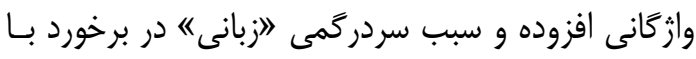

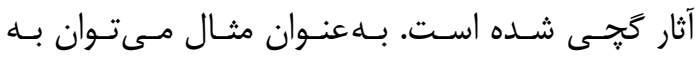

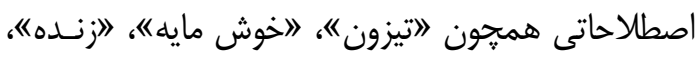

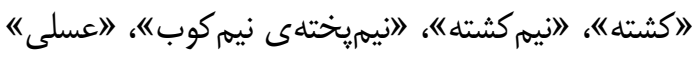

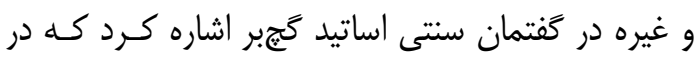

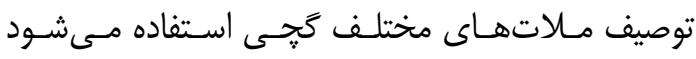

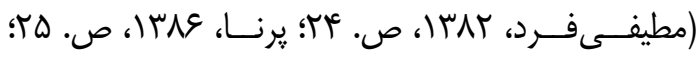

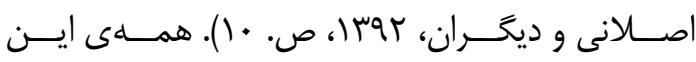

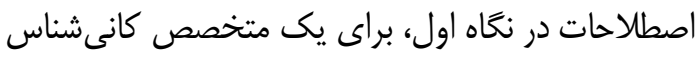

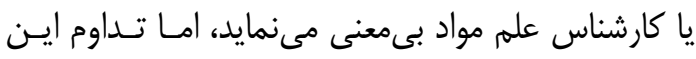

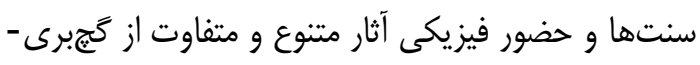

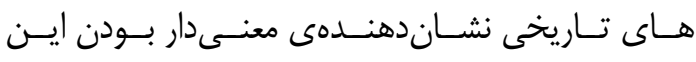
اصطلاحات و نتايج مادى آنها است. مشكل مهارم ديخـر

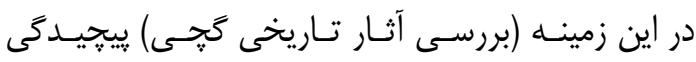

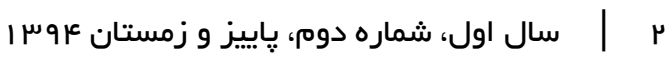


سنجش فضاى خالى بين بلورها در ريزساختار نمونههاى

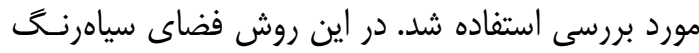

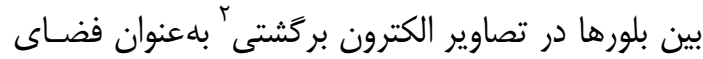

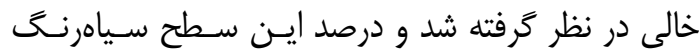
نسبت به كل تصوير توسط نرمافزار مورد بحث محاسـبه

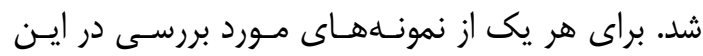
تحقيق حداقل جهار تصوير در هر يك از بزر كنمايىهـاى

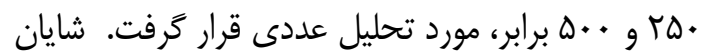
ذكر است كه نتايج اين بررسى متغيرى بصرى را معرفى مرى مى كند كه با تعاريف متداول تخلخل و روشهاين برداى مرسوم

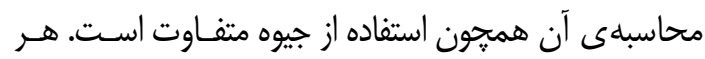

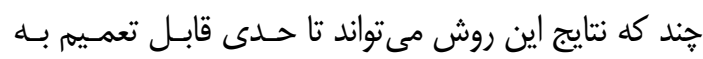

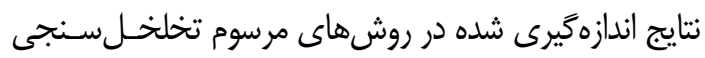
نيز باشد.

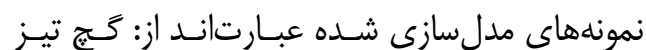

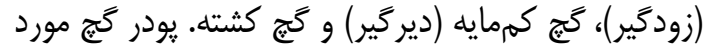
استفاده در اين نمونهها، يودر گج الك شده با ابعـاد مـش . . از كارخانهى "اسييد كَج ساوه" است. براى سـاخت

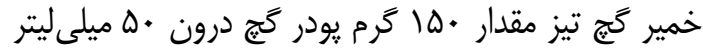

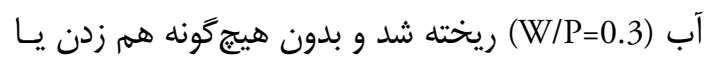

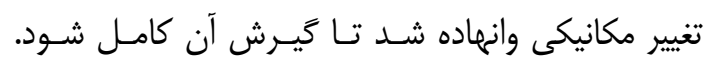

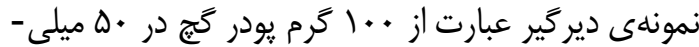

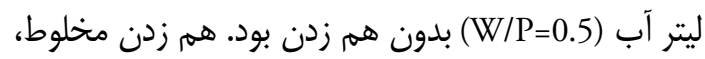

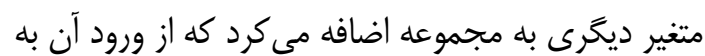
نمونهى گَج تيز و كَ كممايه برهيز شد. براى ساخت كَّ

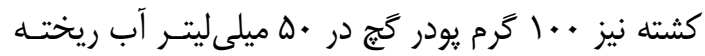

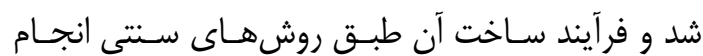

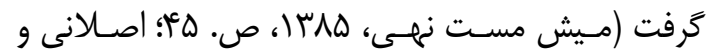

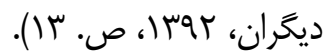
ميكروسكوٍ الكترونى روبشى Philips, XL300 در

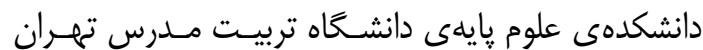
براى نمونههاى كوه خواجه، كج كشتهـ و كَّ كممايسه

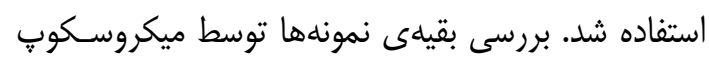

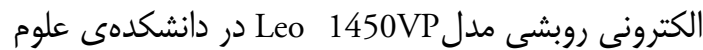

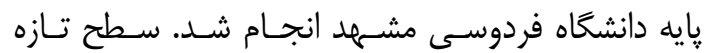

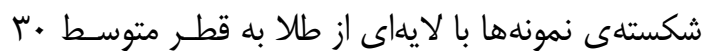

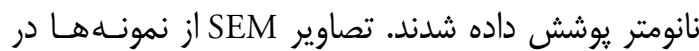
$\mu$

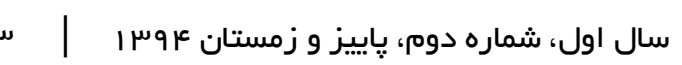

مدل سازى شده بر اساس روشهاى سـنتى و يِيجيـدى ساختار بلورى گَج در شرايط محيطى مختلـف و در كر كنـار مواد كوناكون است. مسئلهى اصلى اين تحقيق ييدا كردن

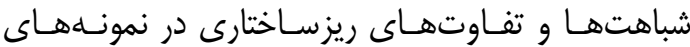
مدل سازى شده و نمونههاى تاريخى، به كمك روشهاى رئهاى آزمايشكاهى است. يرسش اصلى اين است كه نمونههاى تاريخى مورد بررسى خه خصوصيات بلورى و ريزساختارى

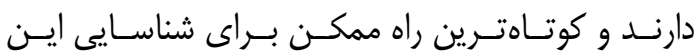

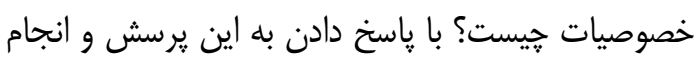

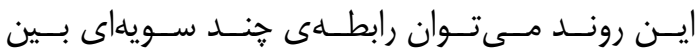
ساختارشناسى، فنشناسى، آسيبشناسى و وازّكان شناسى رونى آثار كَّى تاريخى ايجاد كرد.

\section{r- ب - روش تحقيق}

يزوهش حاضر ابتدا به انجام مطالعـات فنسى در زمينـهى

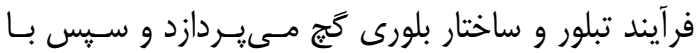

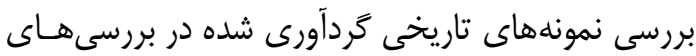

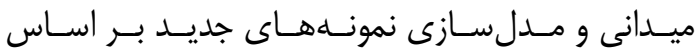

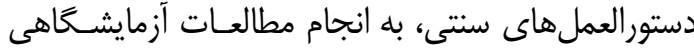
روى اين نمونهها، با استفاده از روشهاى دان دستخاهى شامل تهيهى تصاوير SEM و آزمايش XRD مىيردازد. جامعلى نمي

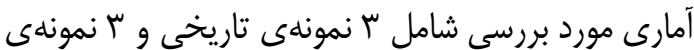

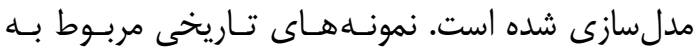

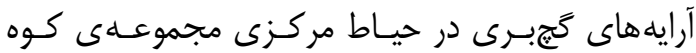

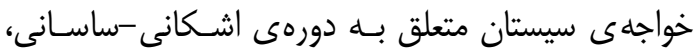
ملات كج نمونهبردارى شده از ديوار برج شـرقى قلعـهى دئى

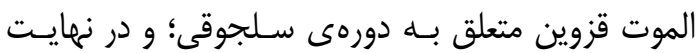
ملات گج مربوط به ديوار تالار عام از مجموعلى تاريخى

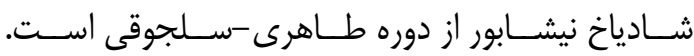

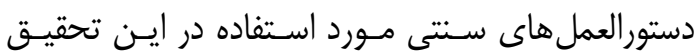
حاصل كفتخوى شخصى نويسنده با برخى اساتيد گَجبر يا تهاي معمار سنتى در منطقهى يزد و اصفيهان (مرحـوم استـاد

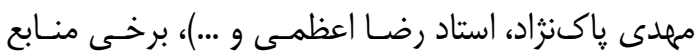

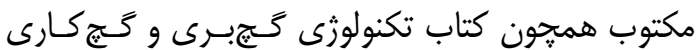

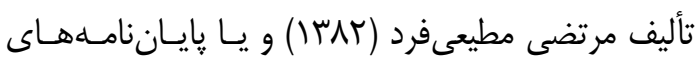
موجود در كتابخانهى داشكاه هنر اصفهان است. نرمافزار يردازش تصوير (JMicro Vison) نسـخهى (V1.27)' در 
اجرايى" ييدا كرد (صالحى كاخكى و اصلانى، •و"1). با

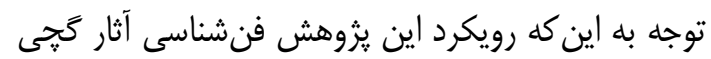

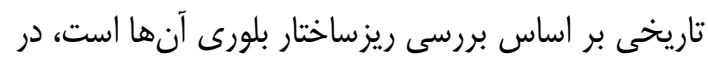

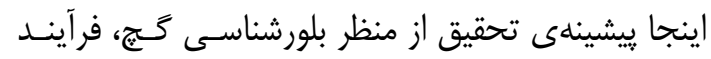

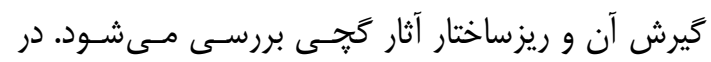

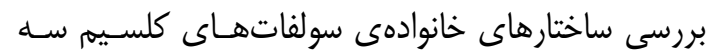

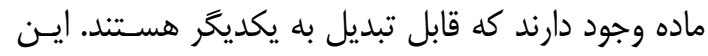

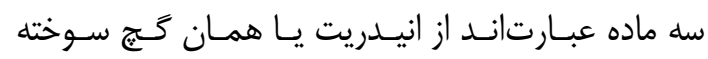
(CaSO $\left.4.0 .5 \mathrm{H}_{2} \mathrm{O}\right)$ (CaSO 4$)$ كه همان يودر كَج قبل از اختلاط با آب است؛ و زئسيس،

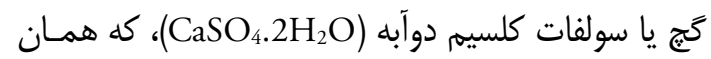

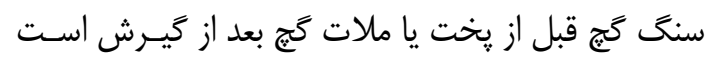

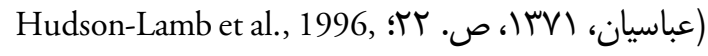

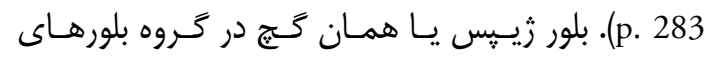

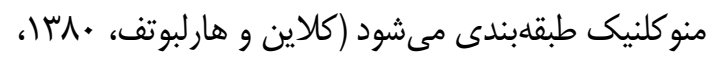

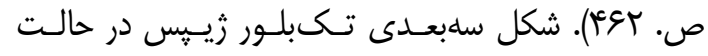

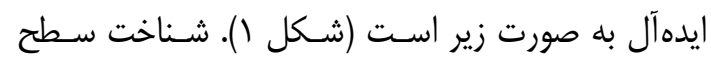

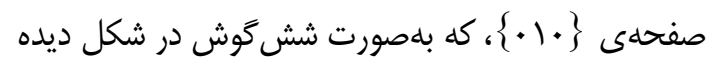

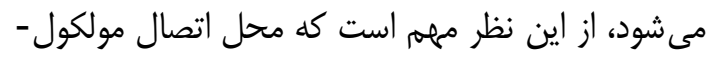

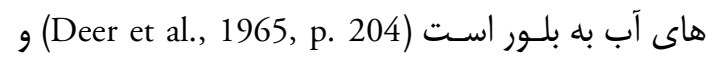

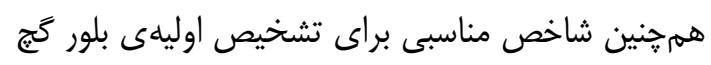

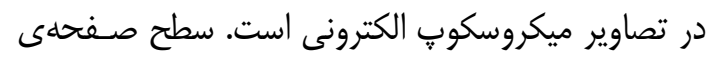

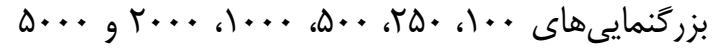

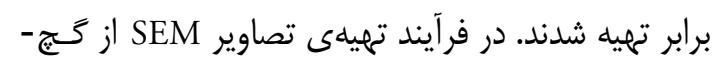

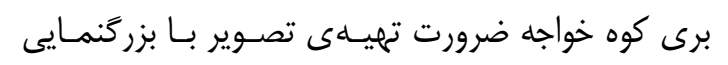

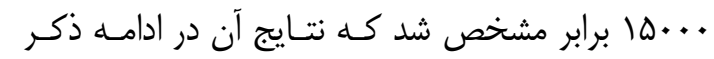

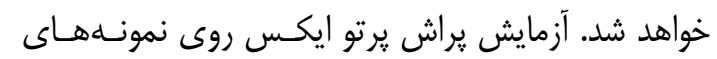

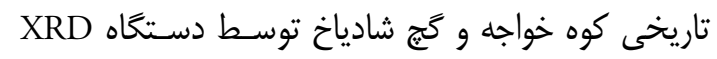
مـدل D8-Advance سـاخت شـركت Bruker AXS، در

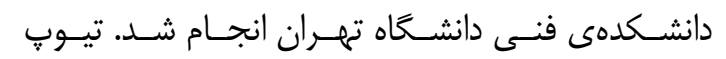
توليدكنندهى يرتو ايكس از جـنس مس (K alpha Cu)

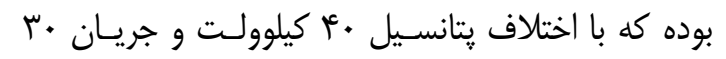

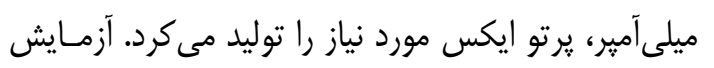

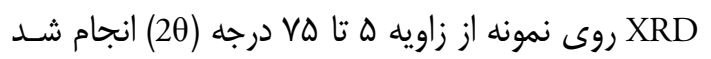

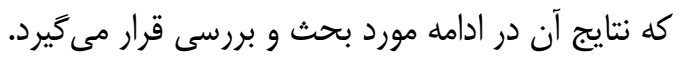

\section{"- بيشينهى تحقيق}

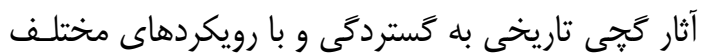

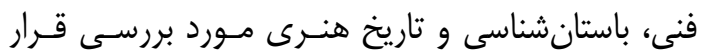

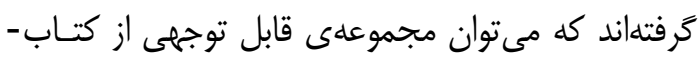

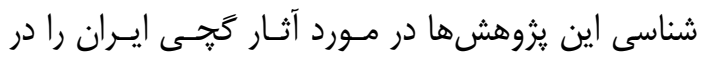

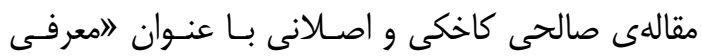

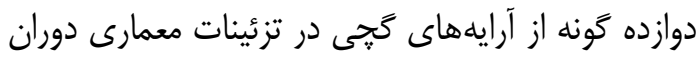
اسـلامى ايـران بـر اسـاس شـَّردهاى فنّى و جزئيــات

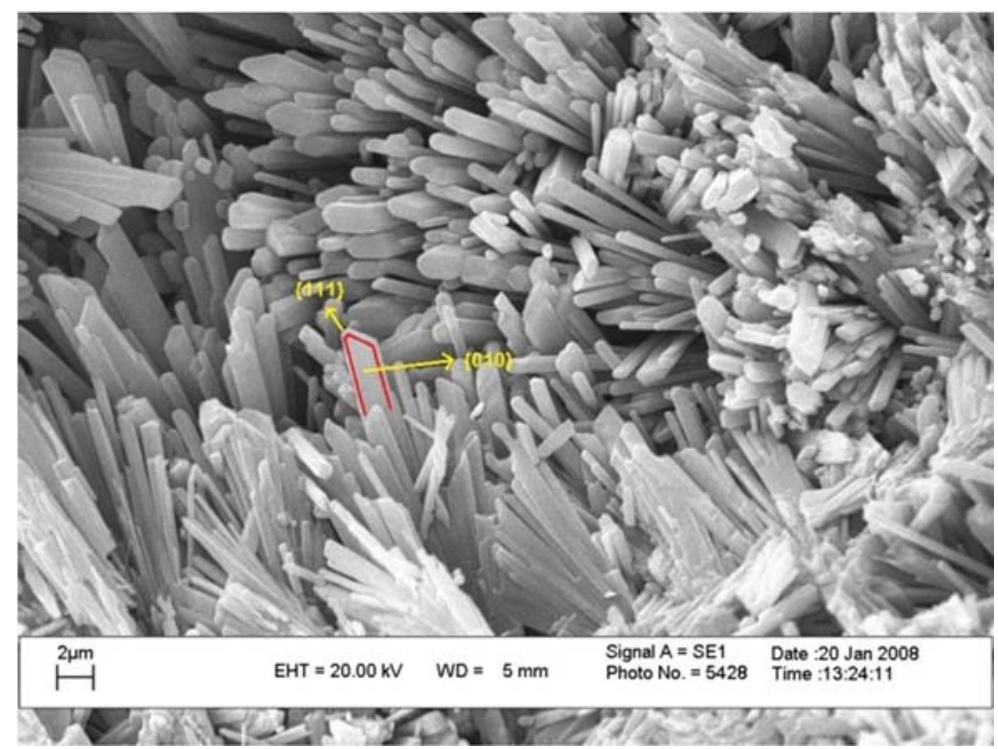

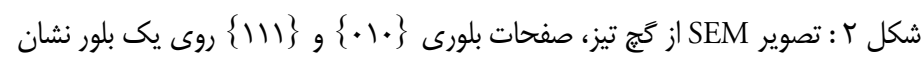

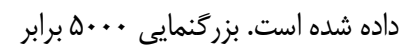

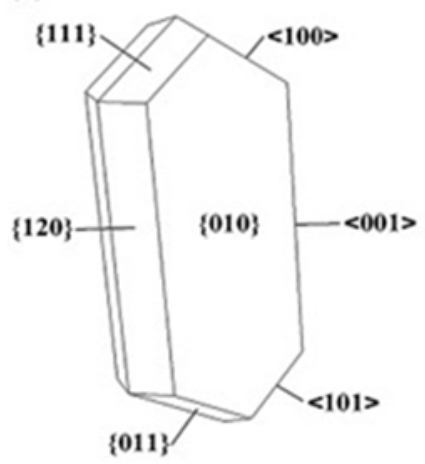

شكل ا: بلور كامل گج و صفحات بلورى آن (Wen-Yi Shih et al., 2005, p. 257) 


\section{f- نتايج و يافتهها}

هدف از تهييه و بررسى نمونههاى ساخته شده بر اسـاس يـ

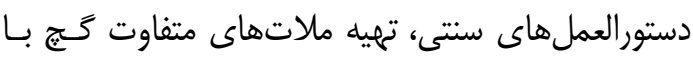

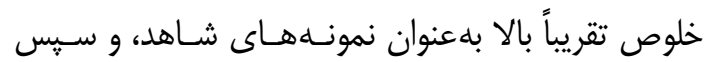

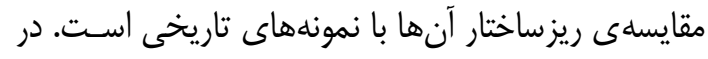

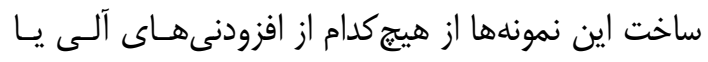
معدنى استفاده نشد و در نتيجه با توجه بـه ايـن شـرايط،

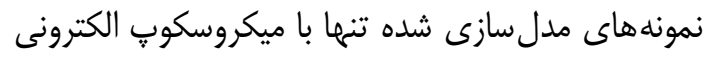
روبشى مورد بررسى قرار گرفتند.

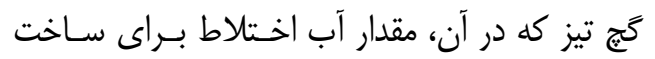

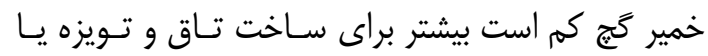
نقاطى كه نياز به ملاتى تندگير و محكم دارنسد، اسـتفاده

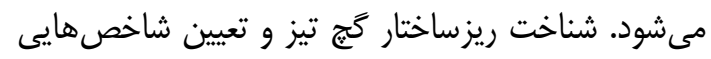

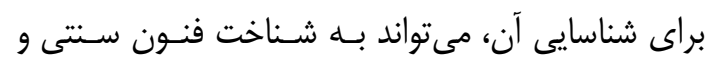

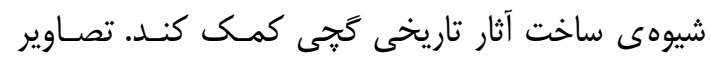

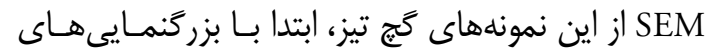

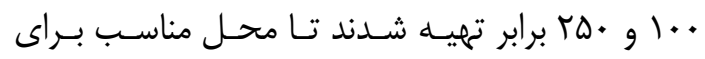

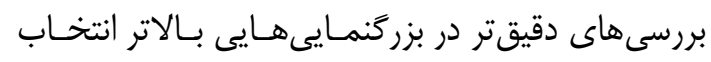

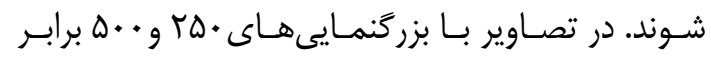

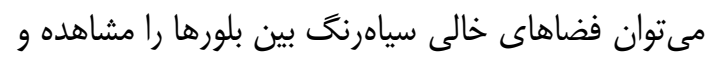

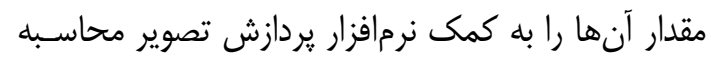
كرد. تصاوير بررسى شده از گج تيز بـا ايـن روش مقــدار

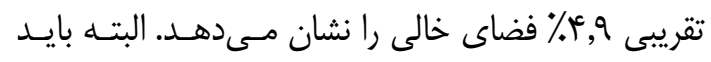

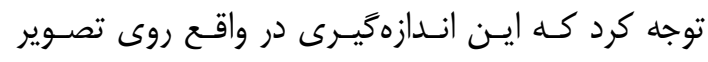
دوبعدى انجام شده است. يكى ديخر از شاخصههاى گَّج

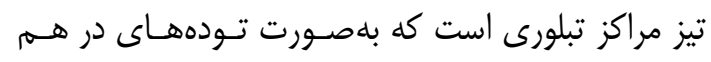
فشرده و گاه فاقد شكل بلورى مشخص ديل ديده مى شوند كه

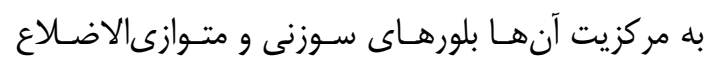

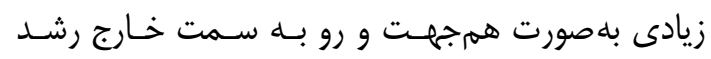

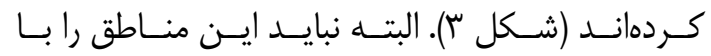

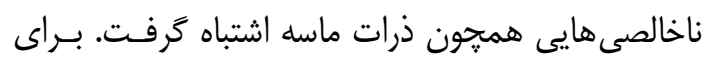

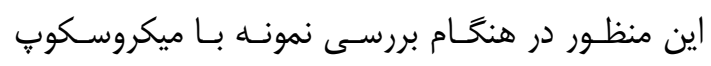

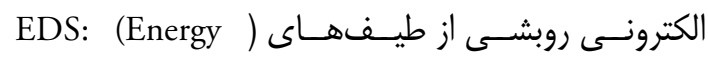
Dispersive Spectroscopy قسمتها بلصورت دقيق مشخص شود. بهعلاوه لازم به

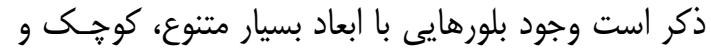

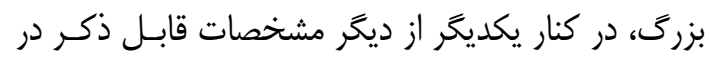

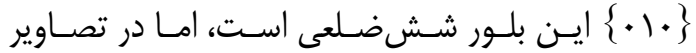
ميكروسكوت الكترونى تقريباً بهصورت متـوازى الاضـلاع

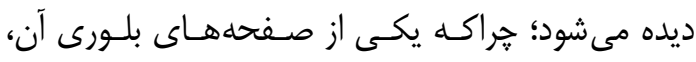
صفحهى \}\} (II)، سريعتر از بقيهى صفحات رشد كرده است (شكل r). در شرايط عادى و بدون وجود مقادير زياد

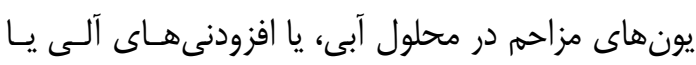
معدنى، بلورهاى سوزنى و تقريباً بلند گج تشكيل مئ مئشوند (Gourdin and kingery, 1975, p. 135)

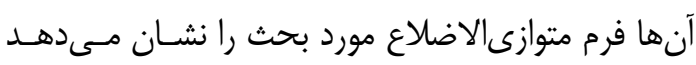

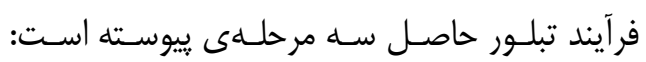

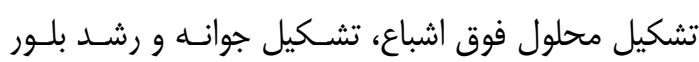

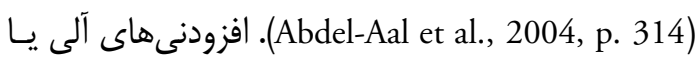
معدنى با تغيير حلاليت يونهاى سـولفات يـا كلسـيم در

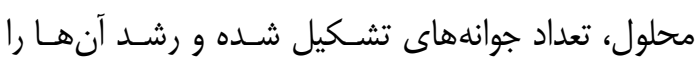

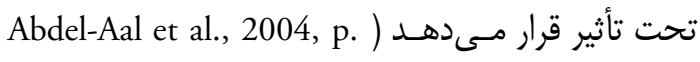

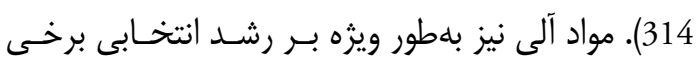

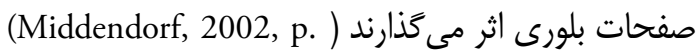
17. با افزايش مقدار افزودنسىهـاى آلى بلى، بلورهـاى كَّج بلوضوح از شكل بلورهاى سوزنى به فرم بلورهايى با قطر

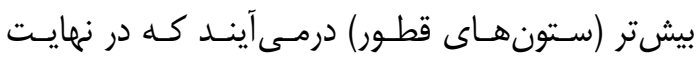

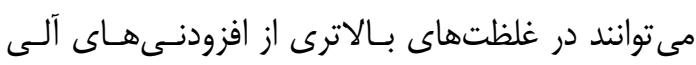

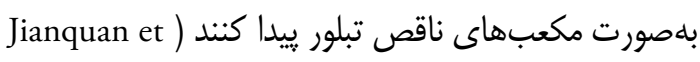
.(al., 2007, p. 875 ريزساختار بسيارى از مواد گجّى تاريخى بـهـصـورت

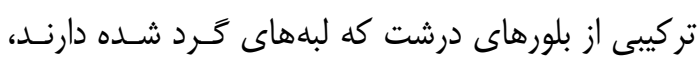
توصيف شده است. برخى از يزوهشخَران وجود بلورهـاى

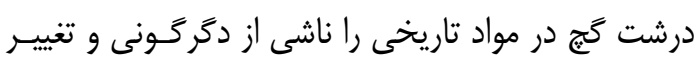

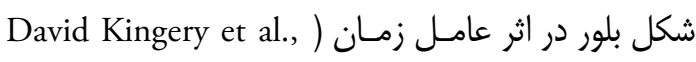
كله

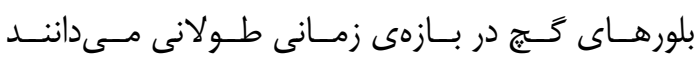
(Middendorf, 2002, p. 169) برخى از ملاتهاى گَج دورهى ساسانى معروف به نسيم-

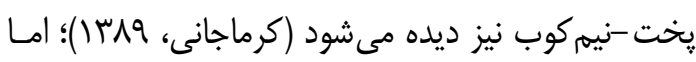

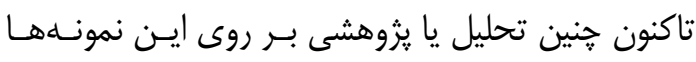

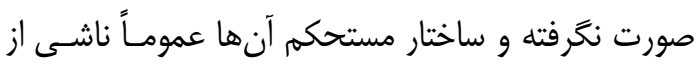
تكنيك فرآورى آنها انگًاشته شده است. 


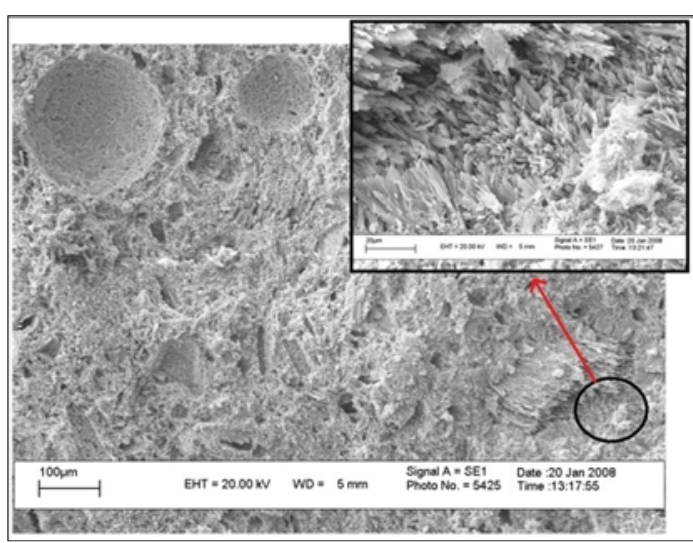

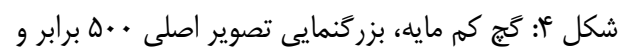

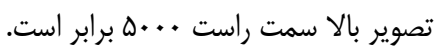

(تشكيل بلورهاى زييس) سخت مى شود (در ايـن مرحلـهـ

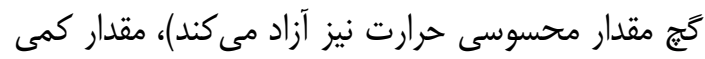

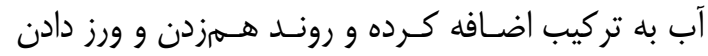

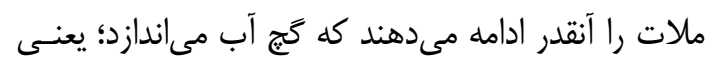

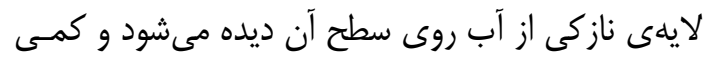
هم سرد مىشود (حرارت مرحله قبل را از دست مى دهائ)

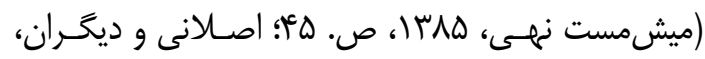

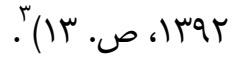
تصاوير SEM از كَ كشته مقدار زيادى از بلورهـاى

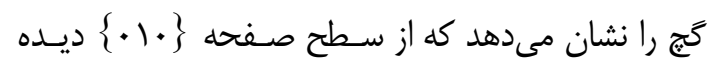
مى شوند (شكل ه). در اين ساختار انــازه و فــرم بلورهـا

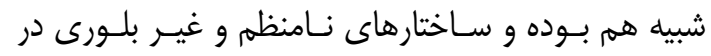
تصاوير SEM ديده نمى شود. مقدار تقريبى فضاهاى خالى نالى

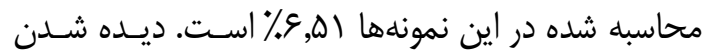

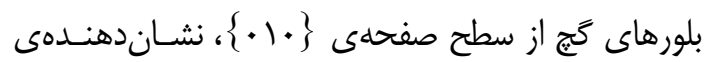

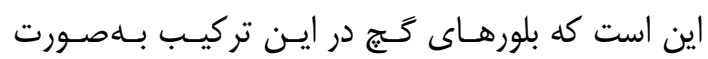

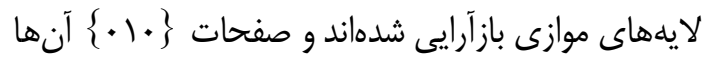

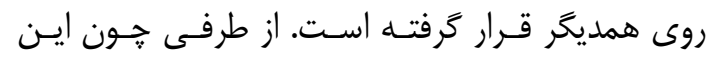

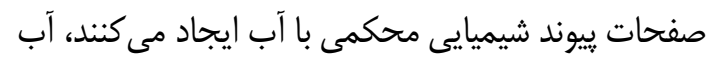

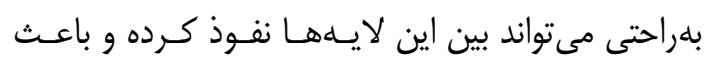

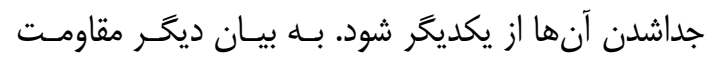

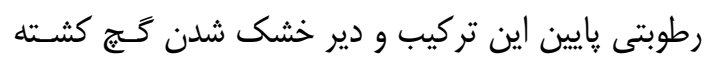
ناشى از اين آرايش بلورى ويثه است.

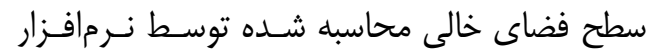

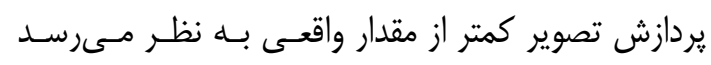

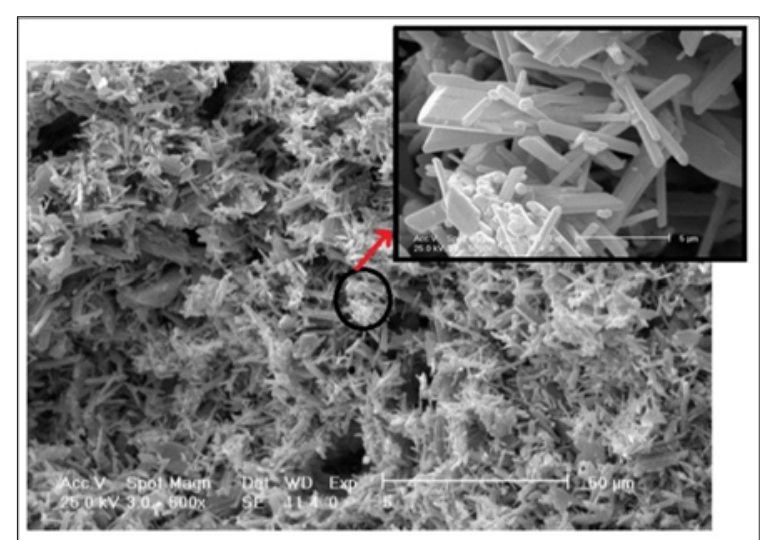

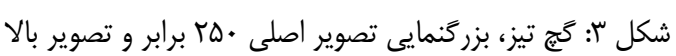
سمت راست ... - ب برابر است.

$$
\text { مشاهدهى ريزساختار گَج تيز است. }
$$
كج كمايه يا ير آب، ملاتى است كه بـ با مقدار زياد آب مآب

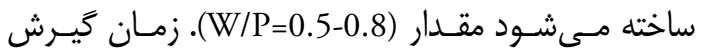

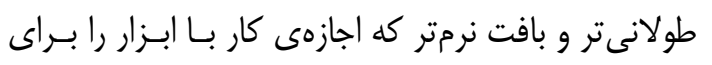

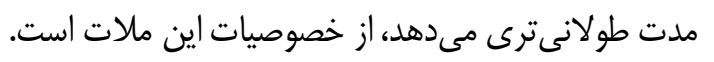

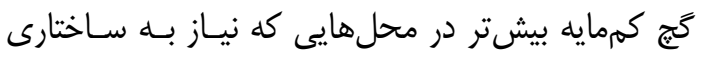

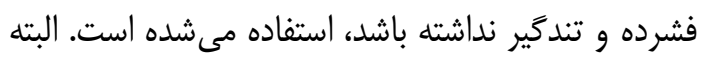

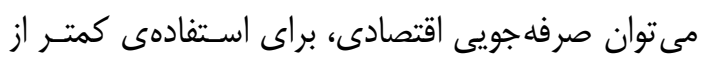

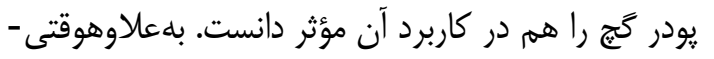

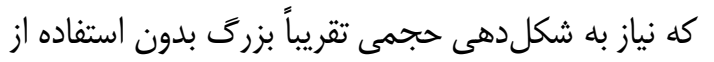
مادهى افزودنى باشد هم مى توان از گجى كممايه اسـتفاده

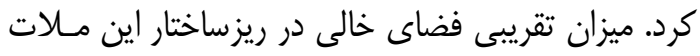

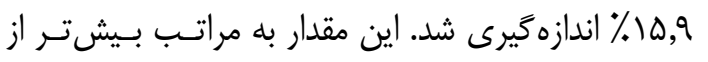

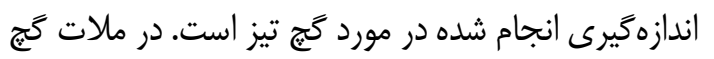
كممايه، برخلاف كج تيز، مناطقى فاقد شكل مشخص كاني كه

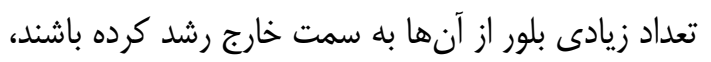

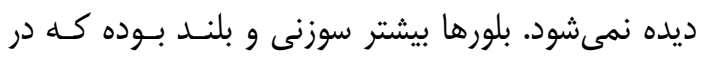

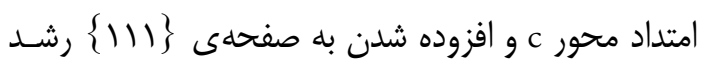

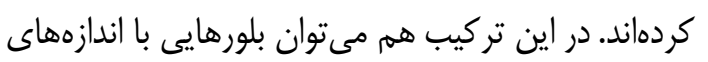
مختلف و متنوع مشاهده كرد (شكل عاء).

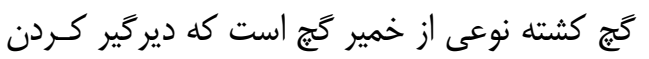
آن به روش مكانيكى انجام مى شود. فرآيند سنتى ساخت

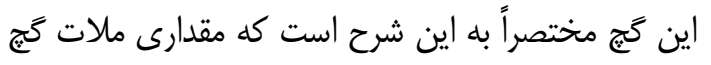

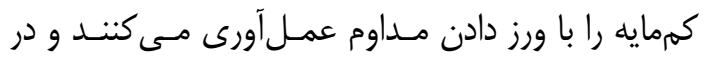

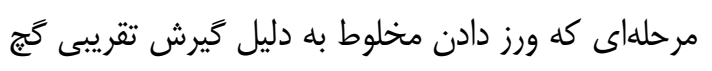




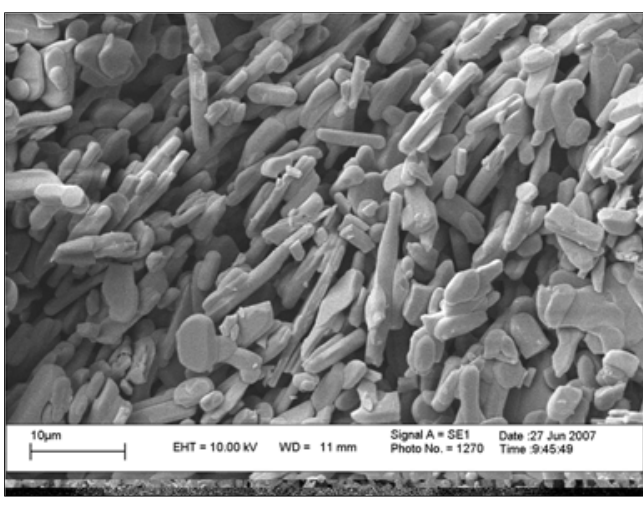

شكل ع: تصوير گج كشته در امتداد لايههاى بلورى موازى، تزئينات

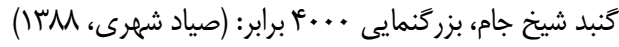

مىدهند كه سطح آنها با مقدارى بسيار زياد از بلورهاى ريزتر يوشيده شده است. اين بلورها در بزرَّمايىهاى

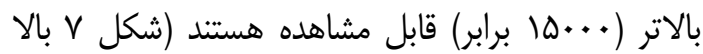
سمت جֶ). اندازهيرى فضاهاى خالى در اين نمونه ميزانى نزديك به ه, •r/\% تخلخل در ريزساختار را نشان

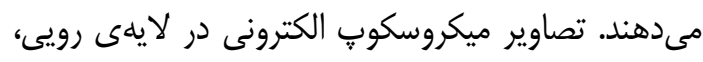

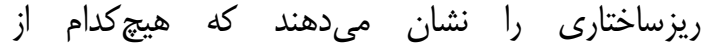

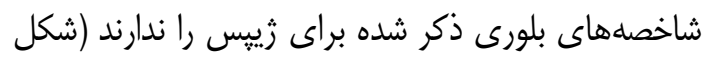

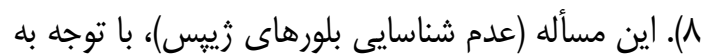
فاز غالب انيدريت در اين لايه، حضور بلورهاى تغيير شكل

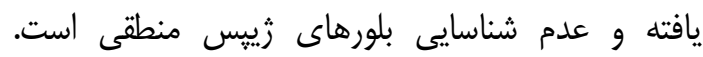

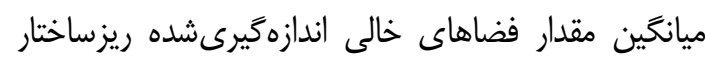

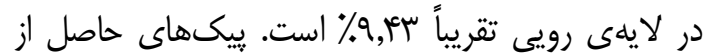

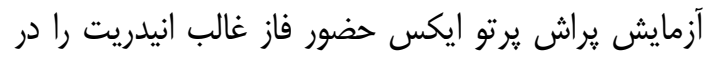

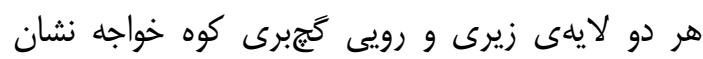

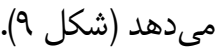
نمونهى تاريخى ديخر، ملات گَج مربوط بـه سـايت

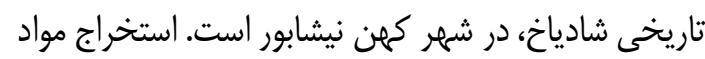

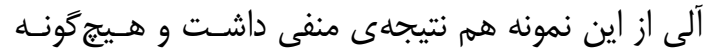

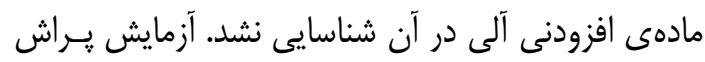

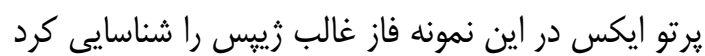

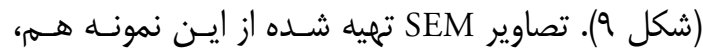

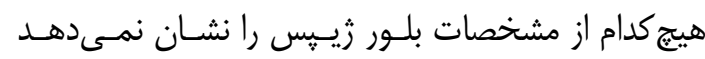
(شكل · (). سنجش فضاهاى خالى در ريزساختار در اين نمونه هم به كمك نرمافزار يردازش تصوير انجام شد كه

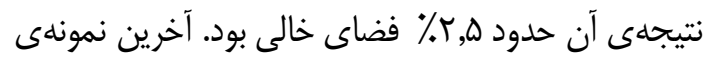
v

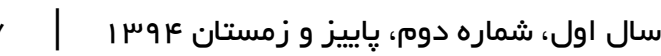

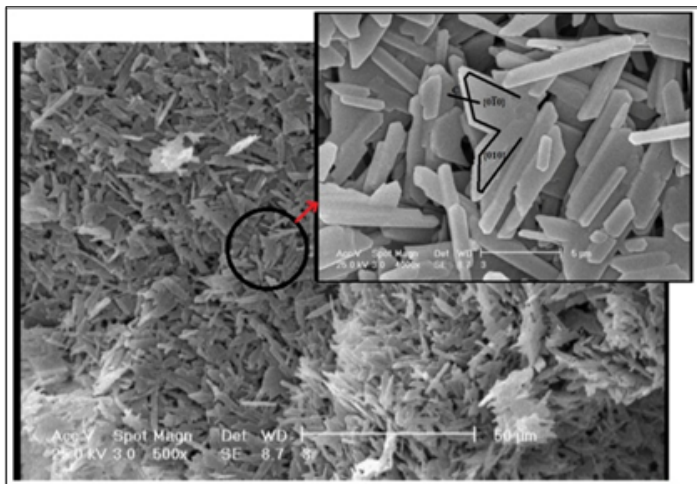

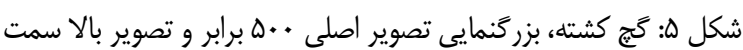
راست ... - مبرابر است.

خراكه در تصويرهاى تهيه شده فقـط سـطح لايسهــاى

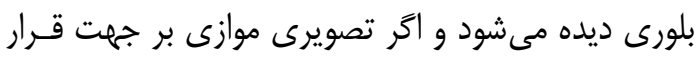
كرفتن صفحات \} • • • مورد تحليل قرار بحيرد نتيجهى متفاوتى خواهد داشت (شكل 9). اصطلاح كَّ نيمكشـته

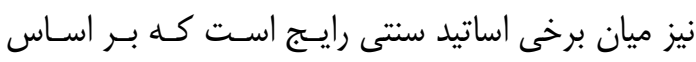
يزوهشهاى انجام شده و مصاحبه با اساتيد سنتى عبارت از تركيب كج كشته همراه با افزودن ثانويـهى يـودر گَّج

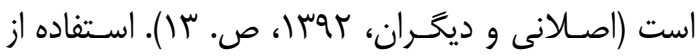
براى تشخيص كانىهاى موجود در كجبـرى كـوه خواجه و ملات كَ شادياخ انجام شد. شناسايى به كمى تلى

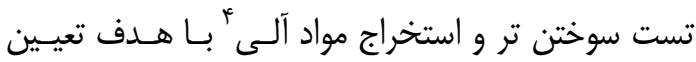

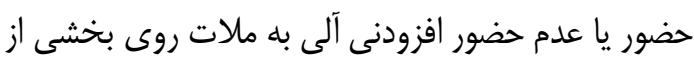

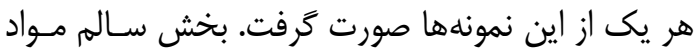
مورد بحث كه مورد تخريب ناشى از سوختن تر يا فرآيند استخراج با محلولهاى قطبى و غير قطبى قرار نخر فتـهـ بود، با ميكروسكوب الكترونى روبشى بررسى شدا. كَبرى كوه خواجه از دو لايهى گَج تشكيل شده كه به لايهى رويى آن بافت بسيار ظريفى دارد، درحالى كه لايهى زيرى دانهبندى درشتترى را نشان مىدهد.

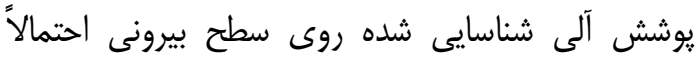
لايهى محافظت كنندهاى بوده كه توسط باستانشناسان در زمان كشف اثر روى آن زده شده است (ميش مست

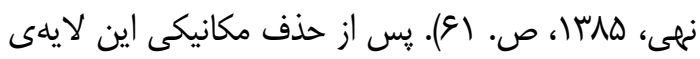

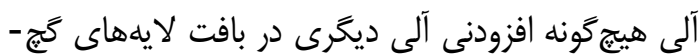
برى شناسايى نشد. تصاوير ميكروسكوٍ الكترونى از لايهى زيرى، بلورهاى تغيير شكل يافته و درشتى را نشان 


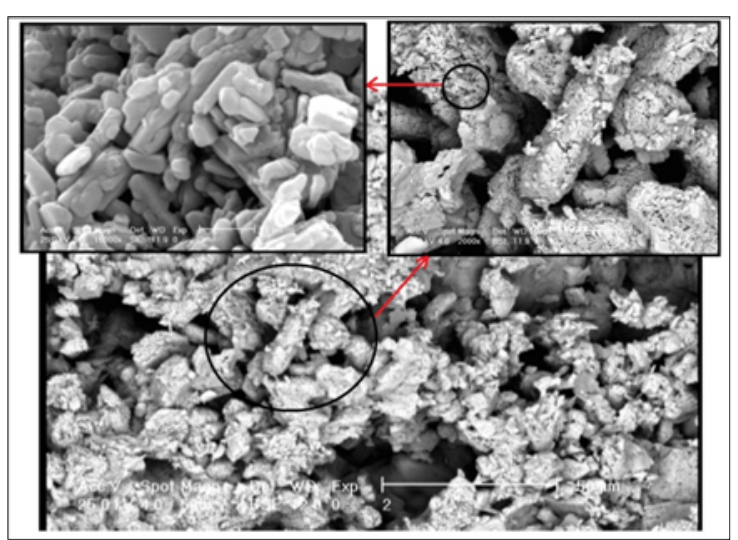

شكل ^(هِ): لايهى رويى كَّبرى كوه خواجه، بزر كنمايى تصوير اصلى

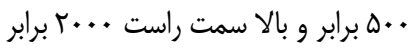

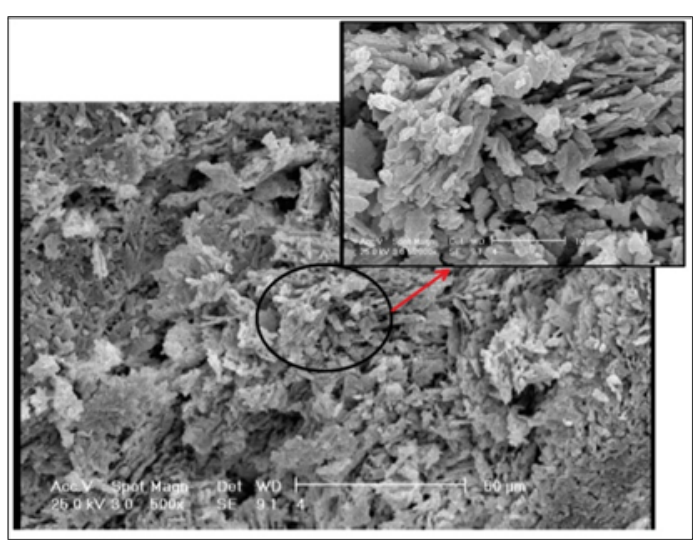

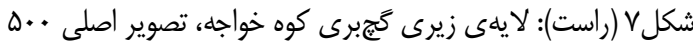

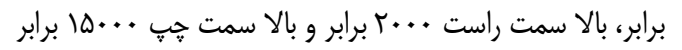

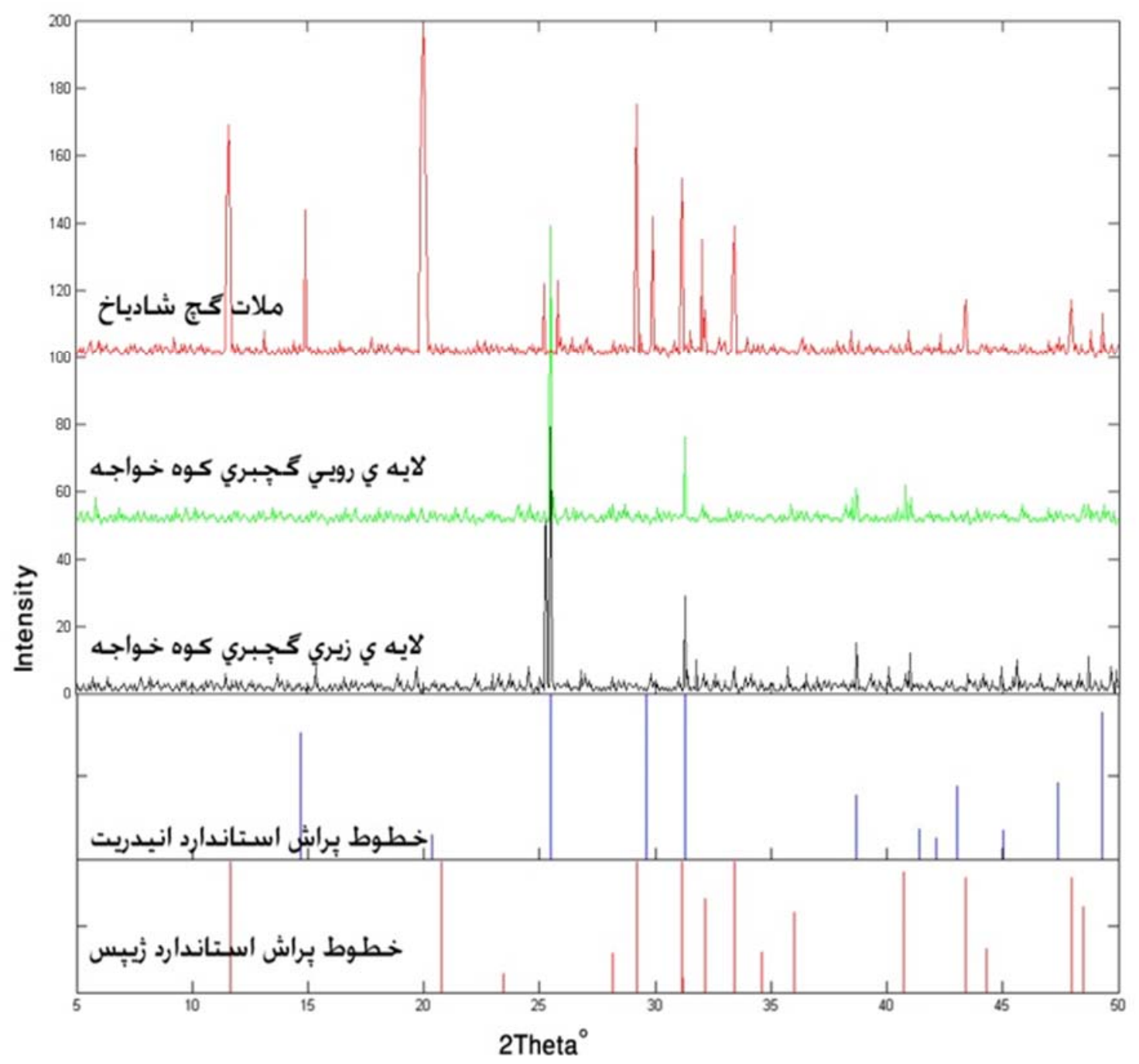

شكل ج: نتايج براش برتو ايكس از نمونههاى تاريخى

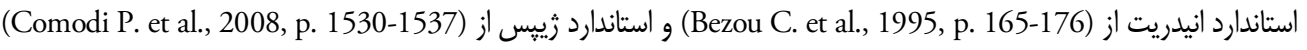




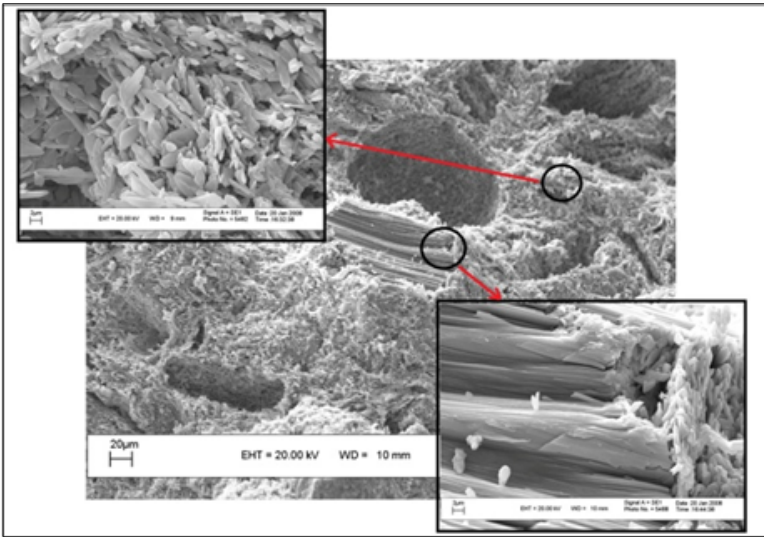

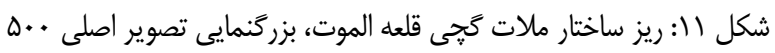
برابر و جزئيات ...0 مبرابر است.

بحيرند. رويكرد استفادهى همزمان از روشهاى مختلـف

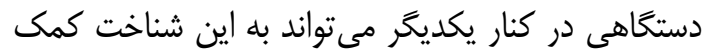

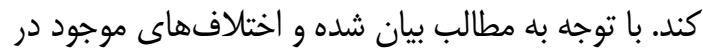

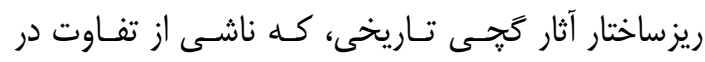

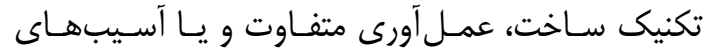

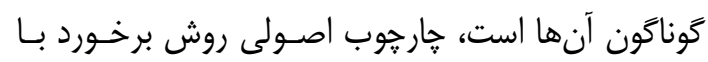

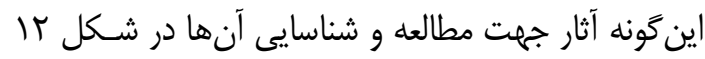

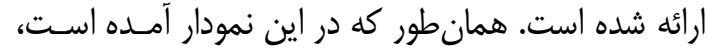

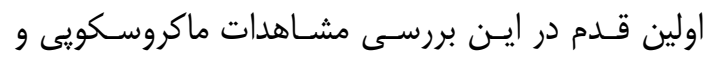
ميكروسكوب نورى است. در اين مرحلـه مسى تـوان آثـار

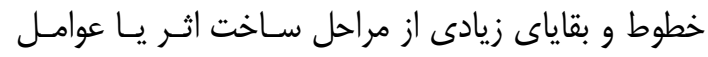

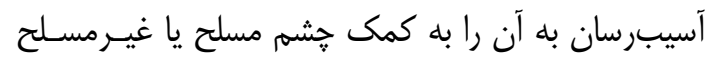
مشاهده و مستندنغارى كرد. در مرحلهى بعد آزمايش يراش يرتو ايكس حضور يـاــا

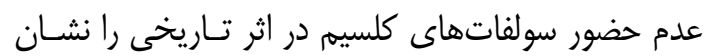

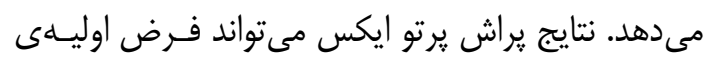
ساخته شدن اثر توسط ملات كَ را اثبات يا رد كند. بـهـ-

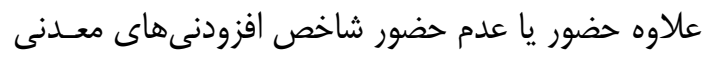

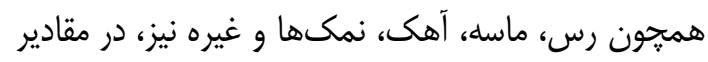

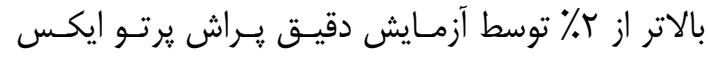
مشخص قابل شناسايى است. سيس بايد شناسايى حضور

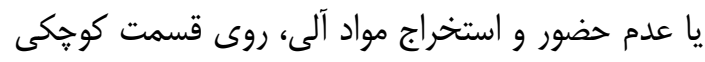

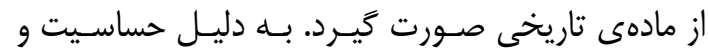

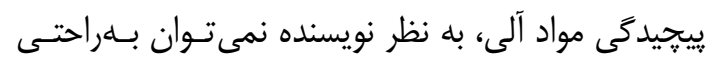

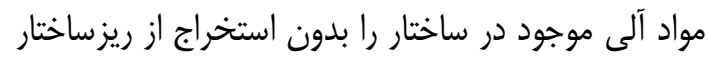

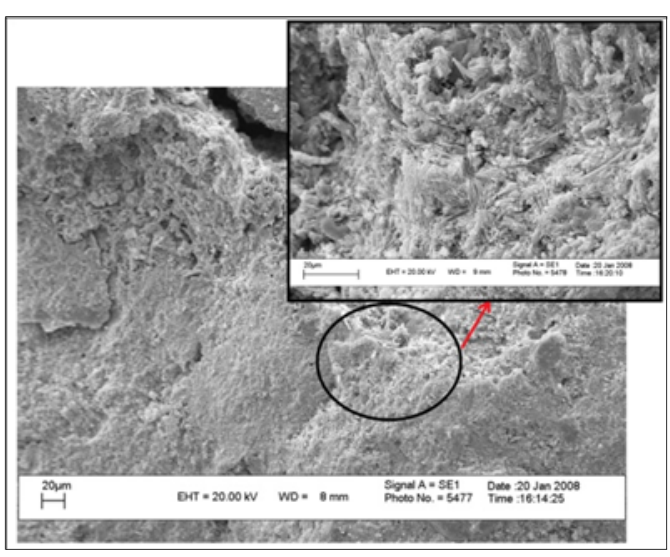

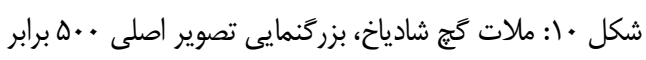

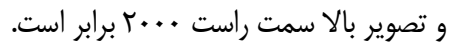

تاريخحى بررسى شده در اين مقاله مربوط بـهـ مـلات گَــ

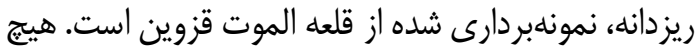

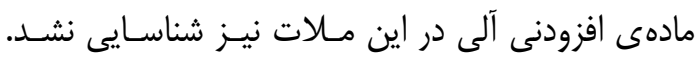

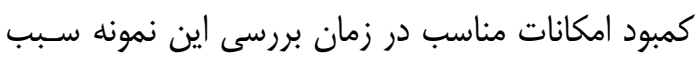

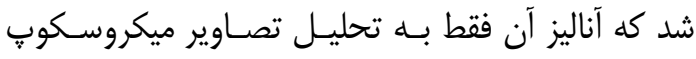

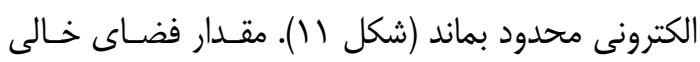

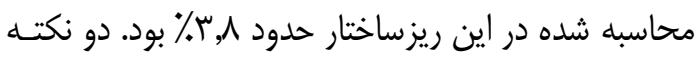

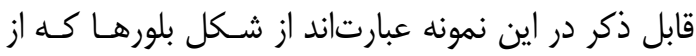

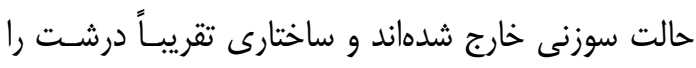

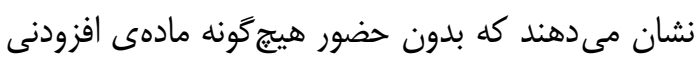

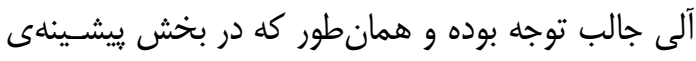

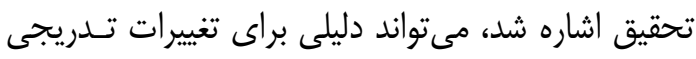

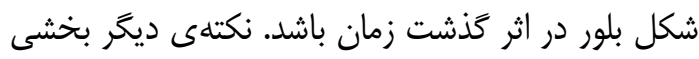

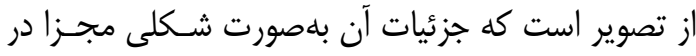

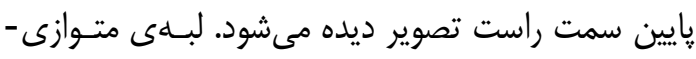

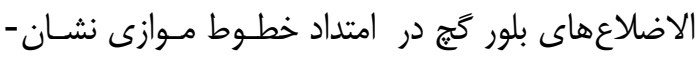
دهندهى ماهيت بلورى زييس براى ساختار ايـن خطوط

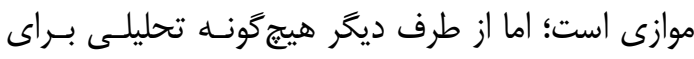

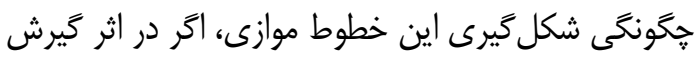
ملات تشكيل شدهاند، ييشنهاد نمى شئود.

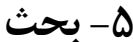

فنشناسى و آسيبشناسى آثار گَّى فرآيندهايى همبافته هستند كه به دليل حساسيت فيزيكى و شيميايى بلور گتج به شرايط محيطى بايد با هم مورد توجه و بررسى قـى قرار 


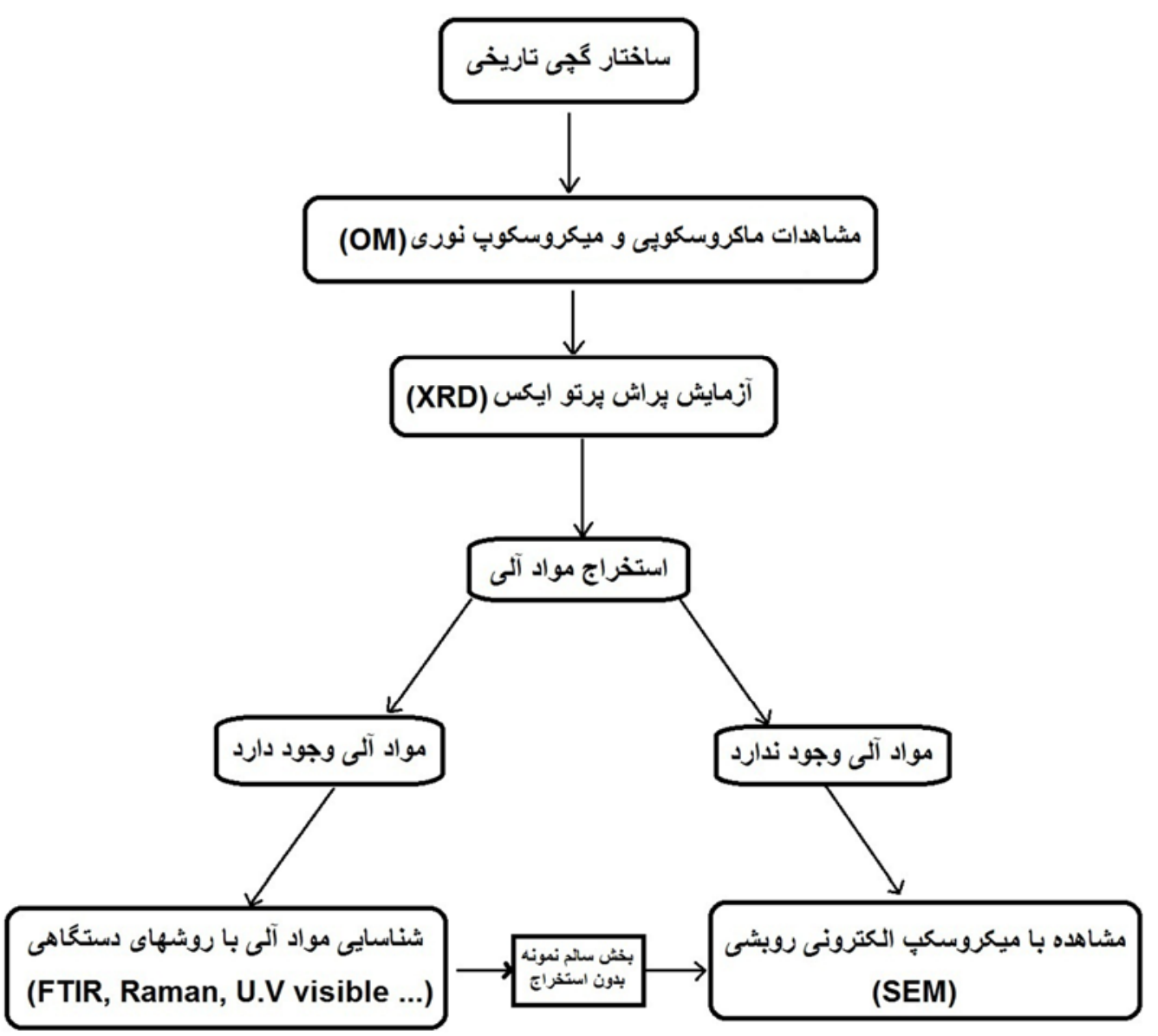

شكل rا: نمودار بيشنهادى بررسى ساختارشناسى آثار كَّى تاريخى

عدم انجام قـــم بــه قـــم مراحـل ذكـر شـــه مـانع از درك

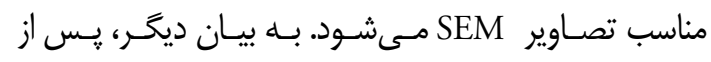

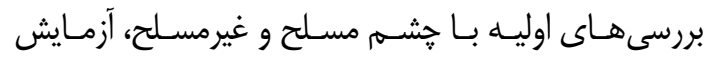

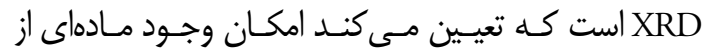

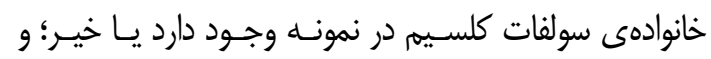
يّ از آن اكر بلور منوكلنيكى در تصـوير SEM ديــده شـد، احتمالاً زييس هست يا نهر بله

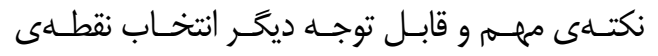

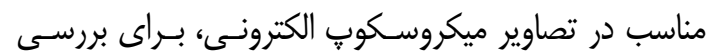

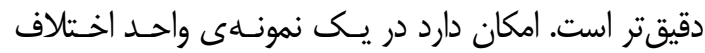

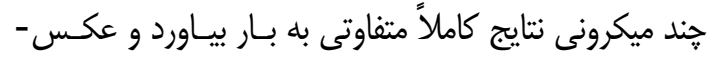

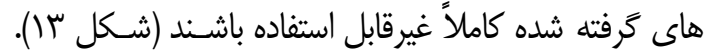

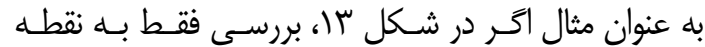

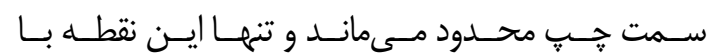
بزر كَنمايىهاى بالاتر بررسى مىشــ؛ هـيج سـاختار بلـورى

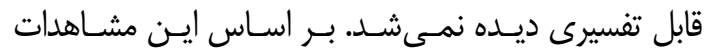

بلورى اثر گَجى شناسايى كرد. ايـن شناسـايى فرآينـدى

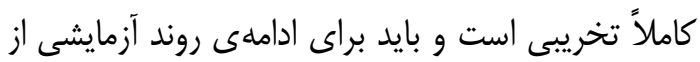

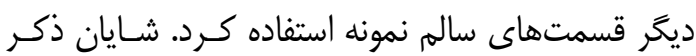

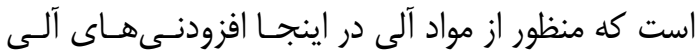
همجون بستها، جسبها، روغنها و موادى از اين قبيل است و نه بقاياى ماكروسكويى ذراتسى همجهـون زغـال، خرده هوب، كاه، مو و غيره. اخــر شناسـايى يـا اسـتخراج

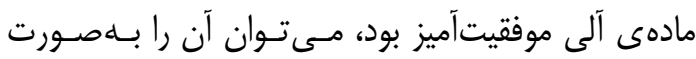

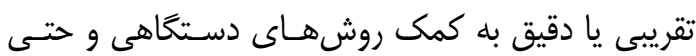

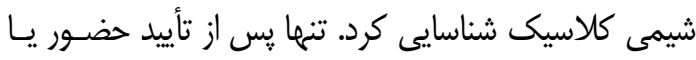

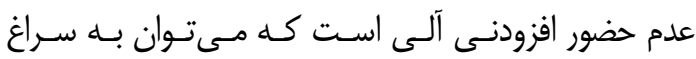

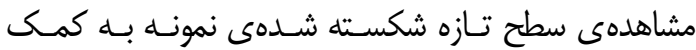
تصاوير ميكروسكوٍ الكترونى روبشى رفت. از يـكسـو، بــاــا توجه به اينكه بلورهاى مختلف زيادى بـا شـبكه منوكلنيـى

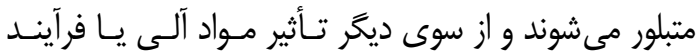
انيدريت شدن تغييرات زيادى در فرم بلورها ايجاد مسى كنـــ م سال اول، شماره دوم، ياييز و زمستان عزوسر 


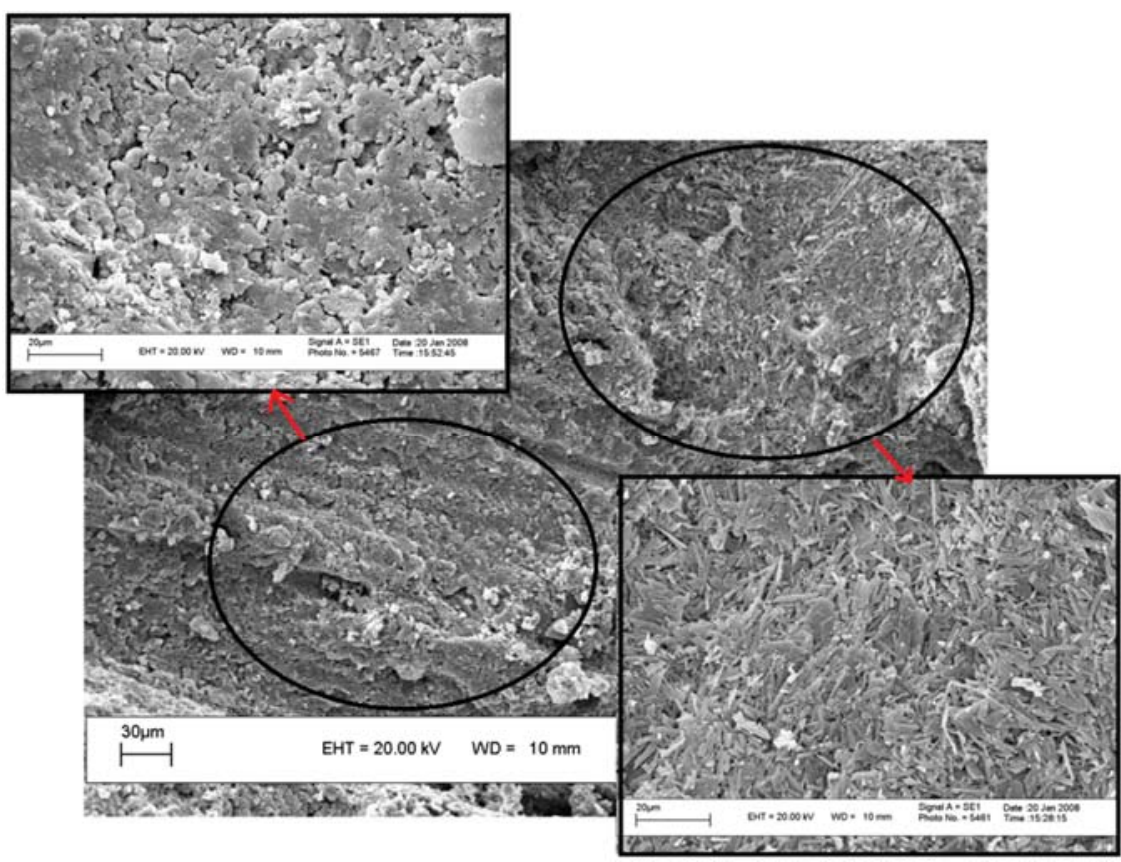

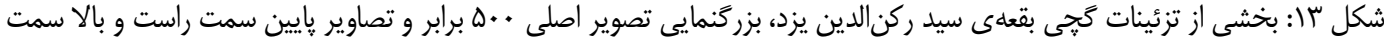

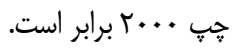

مناسبى است كه به كمك آن بتوان برخى خصوصـيات

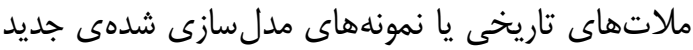

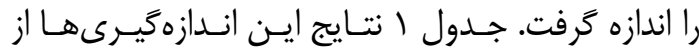
نمونههاى مختلف را نشان مى دهد. بر اساس اين دادههـا مى توان مشاهده كرد كه اولاً ساختار گَج تيـز بـهـوضـوح شامل فضـاى خـالى كمتــى در ريزسـاختارش اسـت و و بهراحتى نسبت به بقيهى ساختارها قابل شناسايى است.

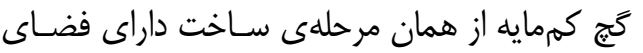
خالى بيشترى نسبت به گج زنده است. گَج يودرى شده كه در آن فرآيند بازتبلور بلهورت بستبت به ريزبلورهاى تشكيل شده روى بلورهاى اصلى ديده مى شوند، داراى بيشترين مقدار فضاى خالى است؛ كه همين موضوع مقاومت كمتر و بــــ

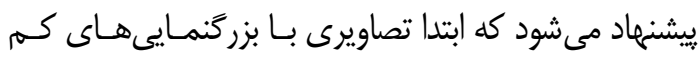

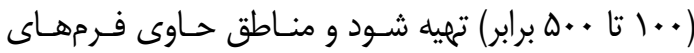

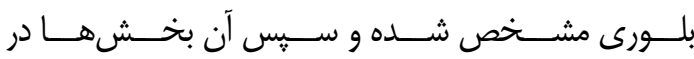

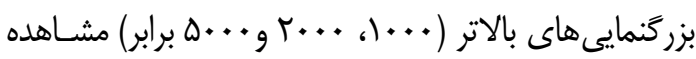

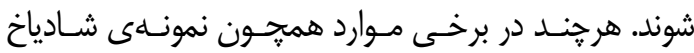
(شكل • (1) ممكن است تصاوير SEM هيج سـاختار بلـورى

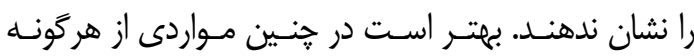

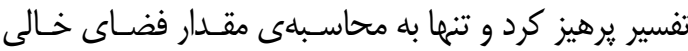
موجود در ريزساختار با نرمافزار يردازش تصوير بسنده كرد.

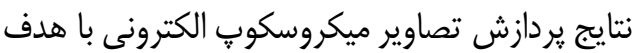

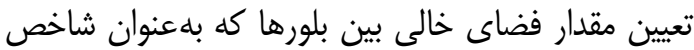

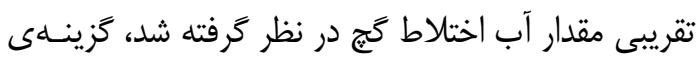

جدول ا: محاسبهى درصد فضاهاى خالى در ريزساختار نمونههاى گَّى بررسى شده توسط نرمافزار تردازش تصوير

\begin{tabular}{|c|c|c|}
\hline انحراف معيار & درصد فضاى خالى در ريزساختار & 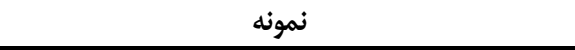 \\
\hline$\% 1,19$ & $\% \uparrow, q$ & كج تيز \\
\hline$\% \cdot, 99$ & $\% 10,9$ & كج كممايه \\
\hline$\% \cdot 9 \Delta$ & $\%,(\Delta)$ & كَج كشته \\
\hline$\%$ & $\%$ \% , Q & گج يودرى و انيدريت شده (كوه خواجه، لايهى زيرى) \\
\hline$\% \cdot 90$ & $\%$ & گَج انيدريت شده (كوه خواجه، لايهى رويى) \\
\hline
\end{tabular}

سال اول، شماره دوهم، ياييز و زمستان ع وسر| | 11 
يديدهى فنشناسى و آسيبشناسـى اثر كَجـى را نشـان

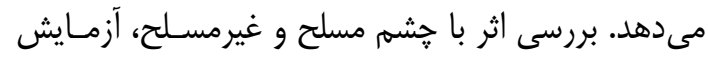
يراش يرتو ايكس و تعيين حضور يا عدم حضـور مـادهى افزودنى آلى، قدمهاى مهمه و اجتنابنايذير هستند كه تنهي

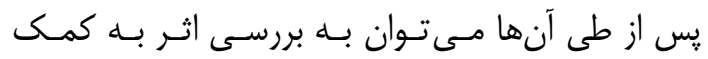

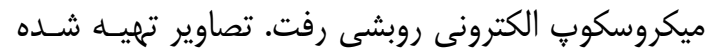

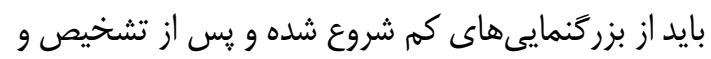

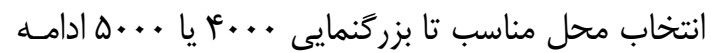
يابد (البته موارد خاص از اين قاعـده مسـتثنا هسـتند). از ماز

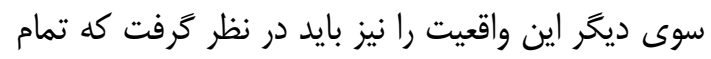
تصاوير گرفته شده هم قابـل تفسـير نيسـتند. در نهايــات

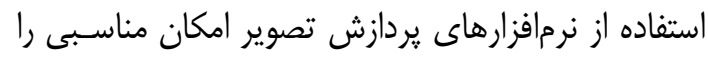

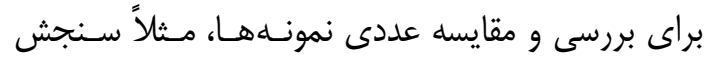

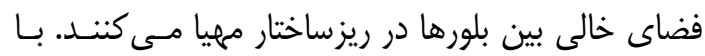

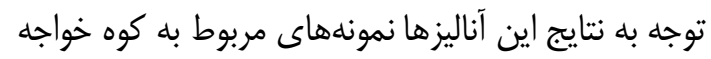
دو آسيب مختلف يا تغيير متفاوت را در ريزساختار نشـان

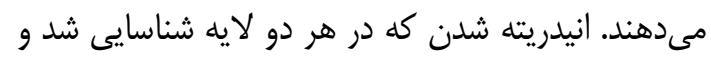

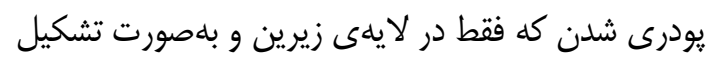

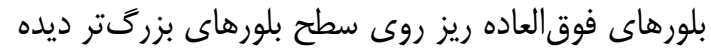

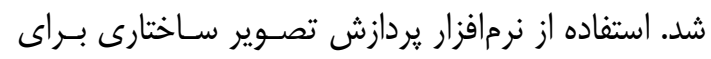

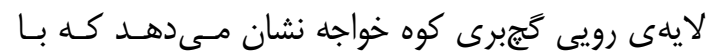

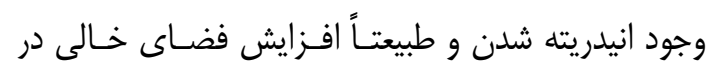

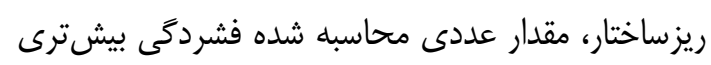

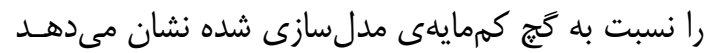

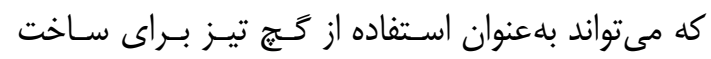

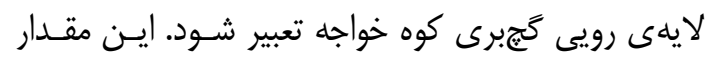

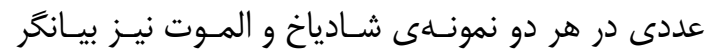

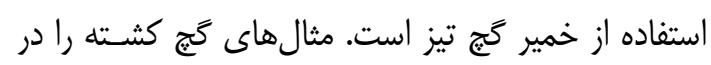

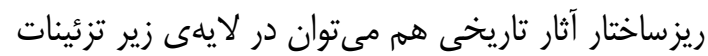

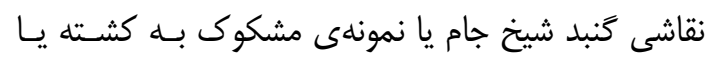

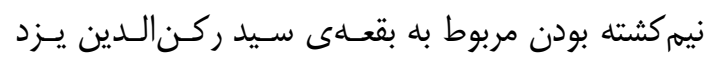
مشاهده و شناسايى كرد.

\section{سياسگزارى}

بخشى از اين مقاله شامل: آناليزهاى مربوط بـه نمونسهى

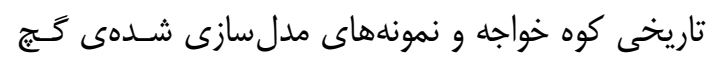

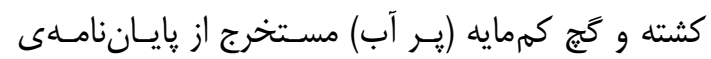

اصطلاح يودرى بودن آن را نيز تبيين مى كند. كَج كشـته

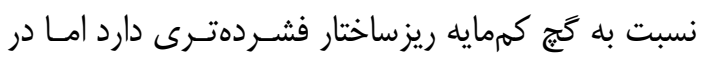

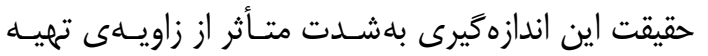
تصوير SEM از گج كشته است. بر خلاف بقيهى نمونهها

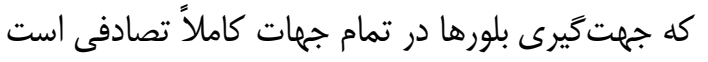

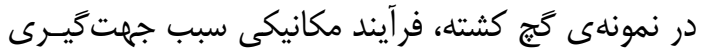

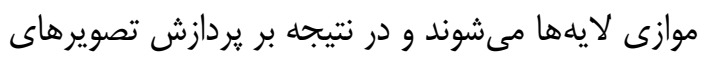

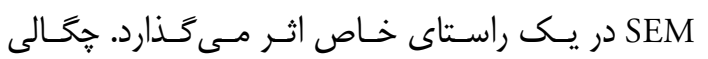

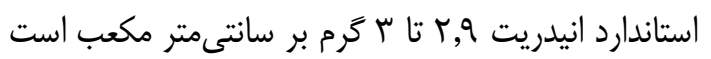

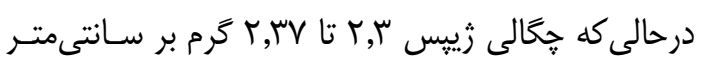

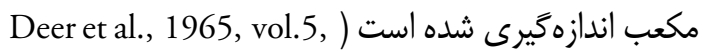

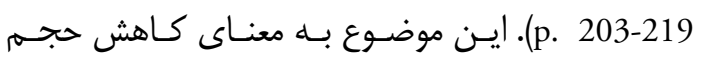

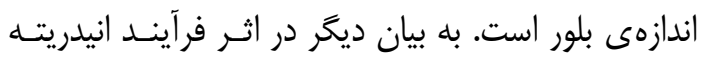

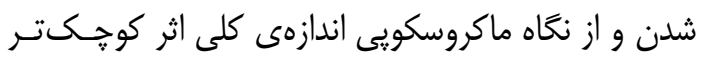

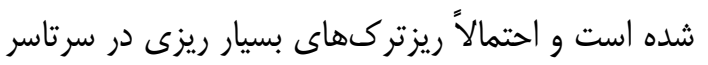

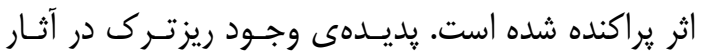

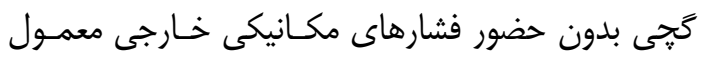

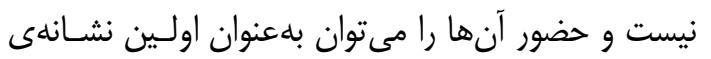

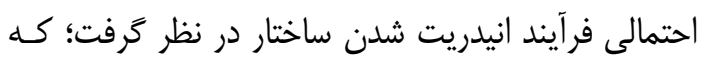

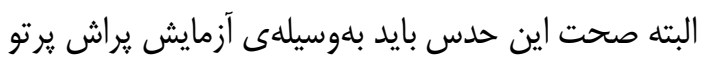

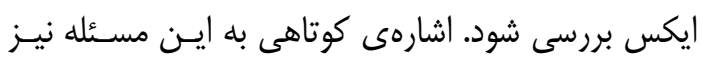

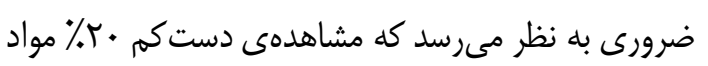

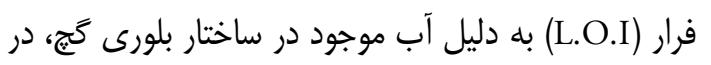

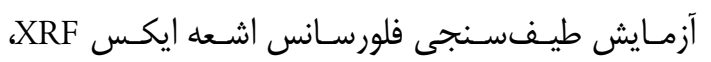

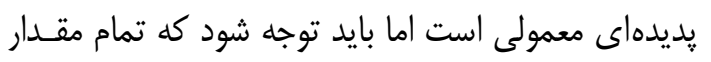

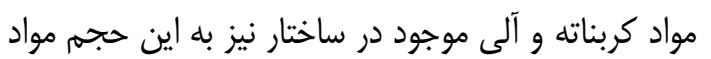

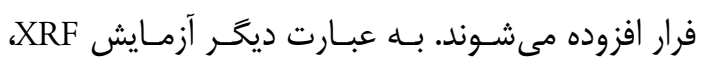

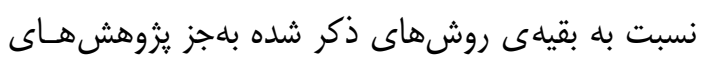

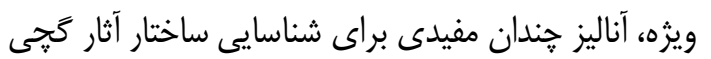
تاريخى نيست.

\section{9- ونتيجه تيرى}

بررسى نمونههاى مدل سـازى شـــه و تـاريخى در كنـار

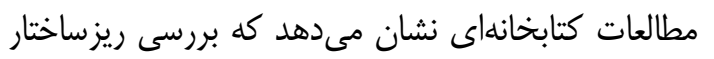

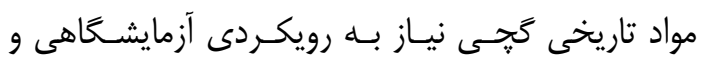

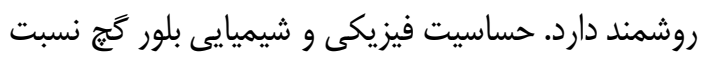

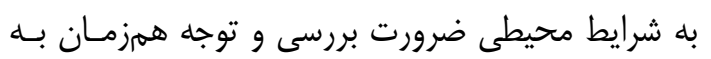




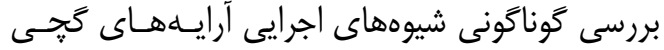

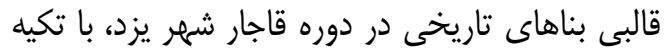

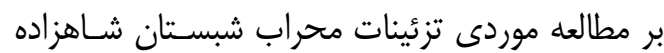

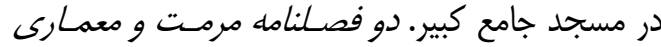

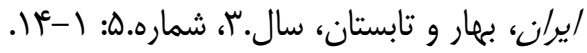

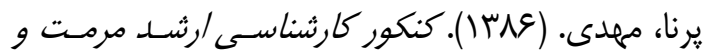
احياى بناهاى تاريخى (كتاب جهارم: آسيبشناسى ارنسان و فنشناسى بناهاى سنتى). تهران: آزاده.

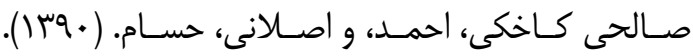

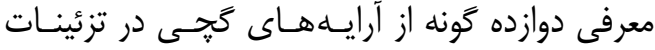

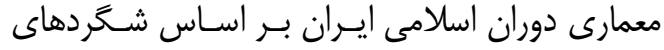

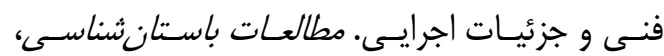
تابستان و ياييز، دوره." ش، شماره. (: 19-9.

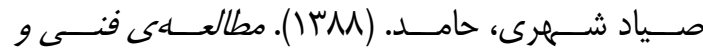

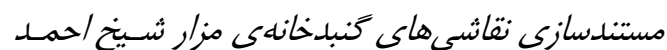
جامى. يايان نامه كارشناسى ارشد. تروه مرمـت اشتياء تاريخى و فرهنگىى. دانشـكده تحصـيلات تكميلى. دانشگاه هنر. عباسيان، مير محمد. ( (III). مبانى شيمى فيزيك كَّ.

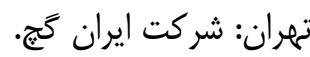

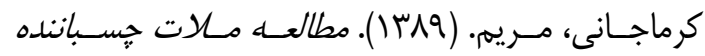
منسوب به دوره ساسانى در بناى معبد آناهيتا كنكاور.

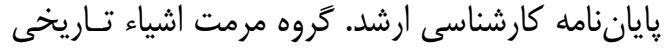
و فرهنگىى. دانشكده مرمت. دانشكاه هنر اصفهان.

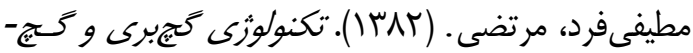
كارى. جلد اول. تهران: مؤسســى فرهنخـى تكـوى

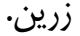

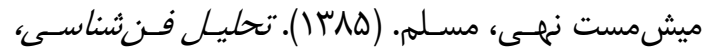

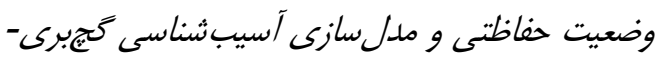

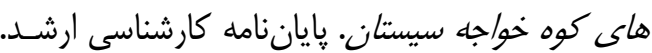

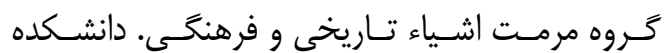

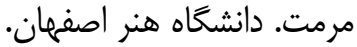

Abdel-Aal, E. A., Rashad, M. M., \& El-Shall, H. (2004). Crystallization of calcium sulfate dihydrate at different supersaturation ratios and different free sulfate concentrations. Crystal Research and Technology, 39(4), 313-321.
كارشناسى ارشد نويسنده در دانشكدهى مرمـت دانشـگاه

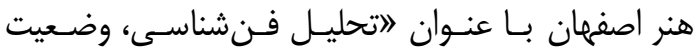

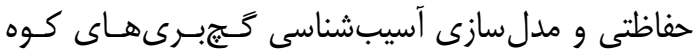

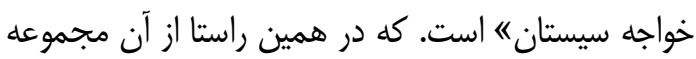

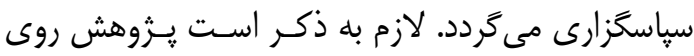

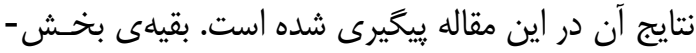
هاى مقاله حاصل فرآيند تحقيقى و نمونهبردارى جنــــين ساله يس از يايان دورهى كارشناسى ارشد است. در پايان

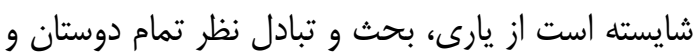

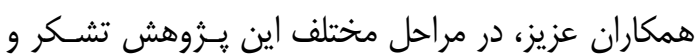

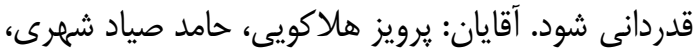

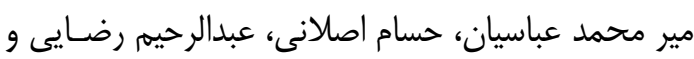
خانمها: نخار افتخارى و عاطفه شكفته.

\section{يقىنوشتها}

1. http://www.jmicrovision.com

2. BSE: Back Scattered Electron

س. تابهحال هيج يزوهش سـنيتيكى يـا ترمودينـاميكى در

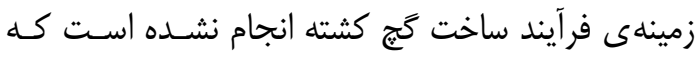

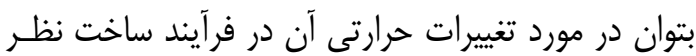

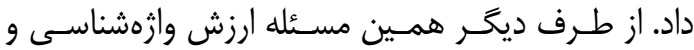

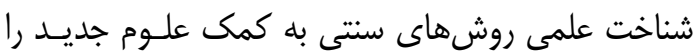
نشان مىدهد و بيان مى كند كه يك اصطلاح در كفتمان

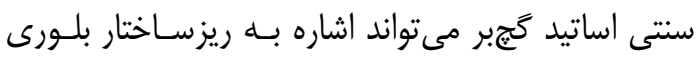
ويثزاى داشته باشد كه تاكنون مورد شناسايى دقيق قـرار نخرخته است. أ. منظور از شناسايى افزودنىهاى آلـى در مرحلـهى اول

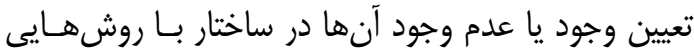
همجون سوختن لاتر يا استخراج با حلالهاى مختلـف وجن

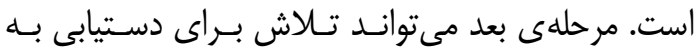

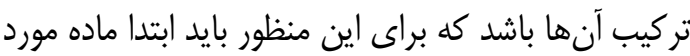
نظر به كمك روشهاى مختلف از جمله قرار حَـرفتن در حلالهاى قطبى يا غير قطبى از ساختار گَج جدا شـود و

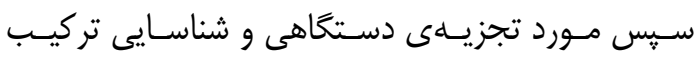
شيميايى قرار بخيرد.

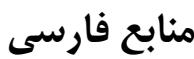

اصلانى، حسام، ميرنيام، آصفه، و علومى، مجيد. (بوسا). 
Bezou, C., Nonat, A., Mutin, J.C., Christensen, A.N., \& Lehmann, M. S. (1995). Of the crystal structure of gamma-CaSO $4, \mathrm{CaSO}_{4} 0.5(\mathrm{H} 2 \mathrm{O})$, and $\mathrm{CaSO}_{4} .0 .6\left(\mathrm{H}_{2} \mathrm{O}\right)$ by powder diffraction methods Locality: Maurienne, France. Journal of Solid State Chemistry, 117:165-176.

Comodi, P., Nazzareni, S., Zanazzi, P. F., \& Speziale, S. (2008). High-pressure behavior of gypsum: A single-crystal X-ray study Locality: Valle di Caramanico, Abruzzo, Italy American Mineralogist, 93: 1530-1537.

David Kingery, W., Vandiver, P. B., \& Prickett, M. (1988). The beginnings of pyrotechnology, part II: Production and use of lime and gypsum plaster in the Pre-Pottery Neolithic Near East. Journal of Field archaeology, 15(2), 219-243.

Deer, W.A., Howie, R.A., \& Zussman, J. (1965). Rock-Forming Minerals. Vol. 5, New Yourk: John Wiley and Sons.

Gourdin, W. H., \& Kingery, W. D. (1975). The beginnings of pyrotechnology: Neolithic and Egyptian lime plaster. Journal of Field Archaeology, 2(1-2), 133-150.

Hudson-Lamb, D. L., Strydom, C. A., \& Potgieter,
J. H. (1996). The thermal dehydration of natural gypsum and pure calcium sulphate dihydrate (gypsum). Thermocbimica acta, 282, 483-492.

Jianquan, Li. Guozhong, Li. Yanzhen, Yu. (2007). The influences of gypsum water-proofing additive on gypsum crystal growth. Materials letters, 61(3), 872-876.

Kröger, J. (1982). Sasanidischer Stuckdekor: Ein Beitrag zum Reliefdekor aus Stuck in sasanidischer und frübilsamischer Zeit nach den Ausgrabungen von 1928/9 und 1931/2. Mainz: Philipp Von Zabern.

Middendorf, B. (2002). Physico-mechanical and microstructural characteristics of historic and restoration mortars based on gypsum: current knowledge and perspective. Geological Society, London, Special Publications, 205(1), 165-176.

Shih, W. Y., Rahardianto, A., Lee, R. W., \& Cohen, Y. (2005). Morphometric characterization of calcium sulfate dihydrate (gypsum) scale on reverse osmosis membranes. Journal of Membrane Science, 252(1), 253-263.

Torraca, G. (1982). Porous Building Materials-Materials Science for Architectural Conservation. Rome: ICCROM. 